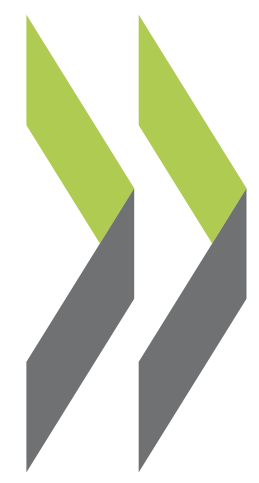

OECD Economics Department Working Papers No. 1218

$$
\begin{array}{r}
\text { Agricultural reforms } \\
\text { and bridging the gap } \\
\text { for rural China }
\end{array}
$$$$
\text { Ben Westmore }
$$ 


\section{Unclassified}

ECO/WKP(2015)36

Organisation de Coopération et de Développement Économiques

Organisation for Economic Co-operation and Development

22-May-2015

ECONOMICS DEPARTMENT

English - Or. English

AGRICULTURAL REFORMS AND BRIDGING THE GAP FOR RURAL CHINA

ECONOMICS DEPARTMENT WORKING PAPERS No. 1218

By Ben Westmore

OECD Working Papers should not be reported as representing the official views of the OECD or of its member countries. The opinions expressed and arguments employed are those of the author(s).

Authorised for publication by Robert Ford, Deputy Director, Country Studies Branch, Economics Department.

All OECD Economics Department Working Papers are available at www.oecd.org/eco/workingpapers

JT03376965

Complete document available on OLIS in its original format

This document and any map included herein are without prejudice to the status of or sovereignty over any territory, to the delimitation of international frontiers and boundaries and to the name of any territory, city or area. 
ECO/WKP(2015)36

OECD Working Papers should not be reported as representing the official views of the OECD or of its member countries. The opinions expressed and arguments employed are those of the author(s).

Working Papers describe preliminary results or research in progress by the author(s) and are published to stimulate discussion on a broad range of issues on which the OECD works.

Comments on Working Papers are welcomed, and may be sent to the Economics Department, OECD, 2 rue André-Pascal, 75775 Paris Cedex 16, France, or by e-mail to eco.contact@ oecd.org.

This document and any map included herein are without prejudice to the status of or sovereignty over any territory, to the delimitation of international frontiers and boundaries and to the name of any territory, city or area.

The statistical data for Israel are supplied by and under the responsibility of the relevant Israeli authorities. The use of such data by the OECD is without prejudice to the status of the Golan Heights, East Jerusalem and Israeli settlements in the West Bank under the terms of international law.

C) OECD (2015)

You can copy, download or print OECD content for your own use, and you can include excerpts from OECD publications, databases and multimedia products in your own documents, presentations, blogs, websites and teaching materials, provided that suitable acknowledgment of OECD as source and copyright owner is given. All requests for commercial use and translation rights should be submitted to rights@oecd.org 


\section{ABSTRACT/RÉSUMÉ}

\section{Agricultural reforms and bridging the gap for rural China}

Urbanisation will continue in China, with the government planning to grant urban residential status to an additional 100 million rural workers by 2020 . While this process is transforming the urban economy, the rural economy is also undergoing substantial structural change. Government policy settings in rural areas are critical for smoothing the transition and helping bridge the gap in living standards between urban and rural China. Reforms should further enable farmers who wish to continue working in the agricultural sector to raise productivity levels. Specific measures include encouraging land transfer, promoting further rural financial development and technical assistance for farmers. At the same time, obstacles should be removed for those rural residents aspiring to move to jobs in cities where their skills can yield a higher marginal product. For those who remain in rural areas, improved social welfare systems and investment in health services are critical.

This Working Paper relates to the 2015 OECD Economic Survey of China www.oecd.org/eco/surveys/economic-survey-china.htm

JEL classification: O13, O18, O53, Q16, P25, I15, H53,

Keywords: China, agricultural reforms, rural development, urbanisation, social welfare.

$* * * * * * * * * * * * * * * * * * * * * * * * * * * * * * * *$

\section{Mener des réformes agricoles et contribuer au rattrapage des zones rurales}

L'urbanisation va se poursuivre en Chine et les pouvoirs publics prévoient d'ailleurs d'accorder le statut de résident urbain à 100 millions de travailleurs ruraux supplémentaires d'ici 2020. Si ce processus a pour effet de transformer l'économie urbaine, l'économie rurale connaît également des changements structurels importants. Dans les zones rurales, les paramètres de l'action publique jouent un rôle clé pour faciliter la transition et contribuer au rattrapage des niveaux de vie entre les villes et les campagnes chinoises. Des réformes devraient être mises en œuvre pour continuer d'aider les agriculteurs qui souhaitent poursuivre leur activité à relever les niveaux de productivité. Encourager la mutation foncière, favoriser la poursuite du développement financier en zone rurale et apporter une assistance technique aux agriculteurs figurent au nombre des mesures à prendre à cet égard. Parallèlement, il faudrait lever les obstacles à la migration des résidents ruraux qui souhaitent occuper un emploi dans les zones urbaines où leurs compétences peuvent assurer un rendement plus élevé. Pour ceux qui restent dans les zones rurales, il est essentiel d'améliorer les systèmes de protection sociale et de développer l'investissement dans les services de santé.

Ce Document de travail a trait à l'Étude économique de l'OCDE de la Chine, 2015

www.oecd.org/fr/eco/etudes/etude-economique-chine.htm

Classification JEL : O13, O18, O53, Q16, P25, I15, H53,

Mots clés : Chine, réformes agricoles, développement rural, urbanisation, protection sociale. 


\section{TABLE OF CONTENTS}

AGRICULTURAL REFORMS AND BRIDGING THE GAP FOR RURAL CHINA...................................5

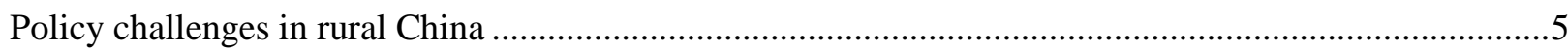

Achieving further productivity gains in the agricultural sector and the non-agricultural rural economy ....9

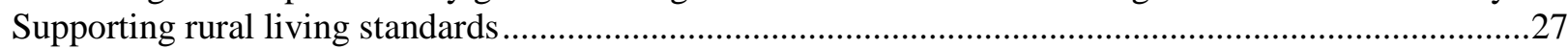

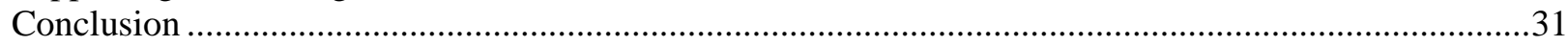

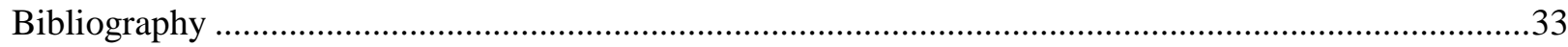

\section{Tables}

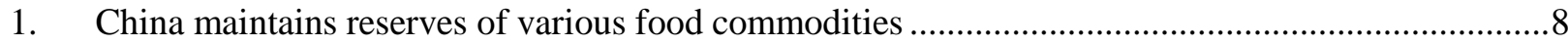

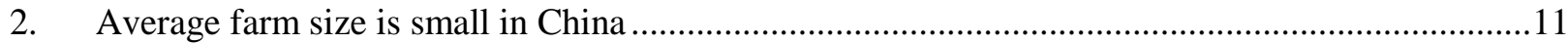

3. Migrant workers have limited access to public services..........................................................16

\section{Figures}

1. The share of agriculture shrinks as economies develop …............................................................

2. Government policies are critical in facilitating rural development ................................................

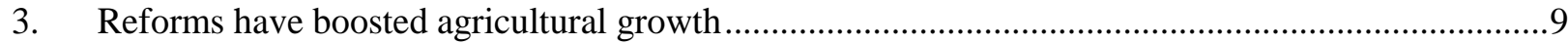

4. Compared with other middle-income countries, agricultural labour productivity is low .................10

5. The proportion of rented farmland has increased but remains below advanced countries ................13

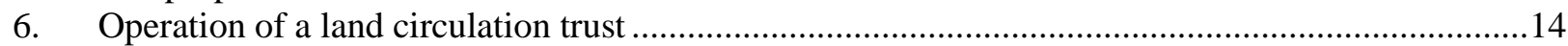

7. Provinces with a high relative wage have attracted migrants ....................................................16

8. Lending to the rural sector has expanded significantly ..........................................................17

9. Proxies for agricultural innovation in China suggest a recent pick-up in activity ..........................20

10. Post-harvest losses of grain are estimated to be highest from poor handling and storage................22

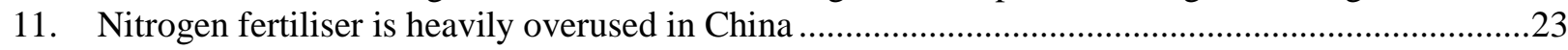

12. China's support for agricultural producers has risen substantially ...........................................27

13. Healthcare services in rural China are low compared with urban areas ........................................31

\section{Boxes}

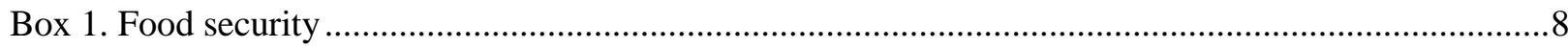

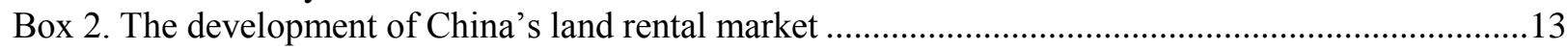

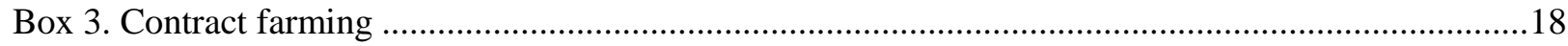

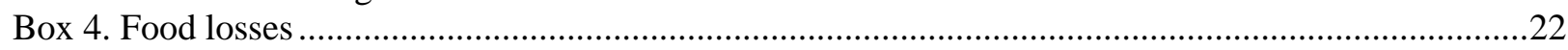

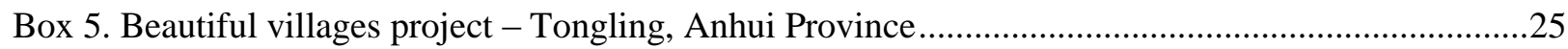

Main policy recommendations on agricultural and rural reform ..........................................................32 


\title{
AGRICULTURAL REFORMS AND BRIDGING THE GAP FOR RURAL CHINA
}

\author{
By Ben Westmore ${ }^{1}$
}

1. Over the past decade, China has experienced unprecedented urbanisation, fuelling economic development that has lifted hundreds of millions of people from poverty and malnutrition and dramatically altered the global economic landscape. While this is transforming China's urban economy, the rural economy is also undergoing substantial structural change. At a time when the government maintains a strong commitment to the goals of food security, reducing urban-rural inequality and protecting natural resources, the development path unfolding in rural areas is of critical importance.

\section{Policy challenges in rural China}

2. As countries develop, the share of agriculture in the overall economy typically diminishes even as the sector's productivity increases. Less productive resources move out of the sector and farmland is consolidated into larger plots that allow for greater mechanisation and more productive farmers to scale up production, gradually moving from labour-intensive to more capital-intensive agricultural production. China is still in the relatively early stages of this process (Figure 1), with the share of agriculture in value

Figure 1. The share of agriculture shrinks as economies develop
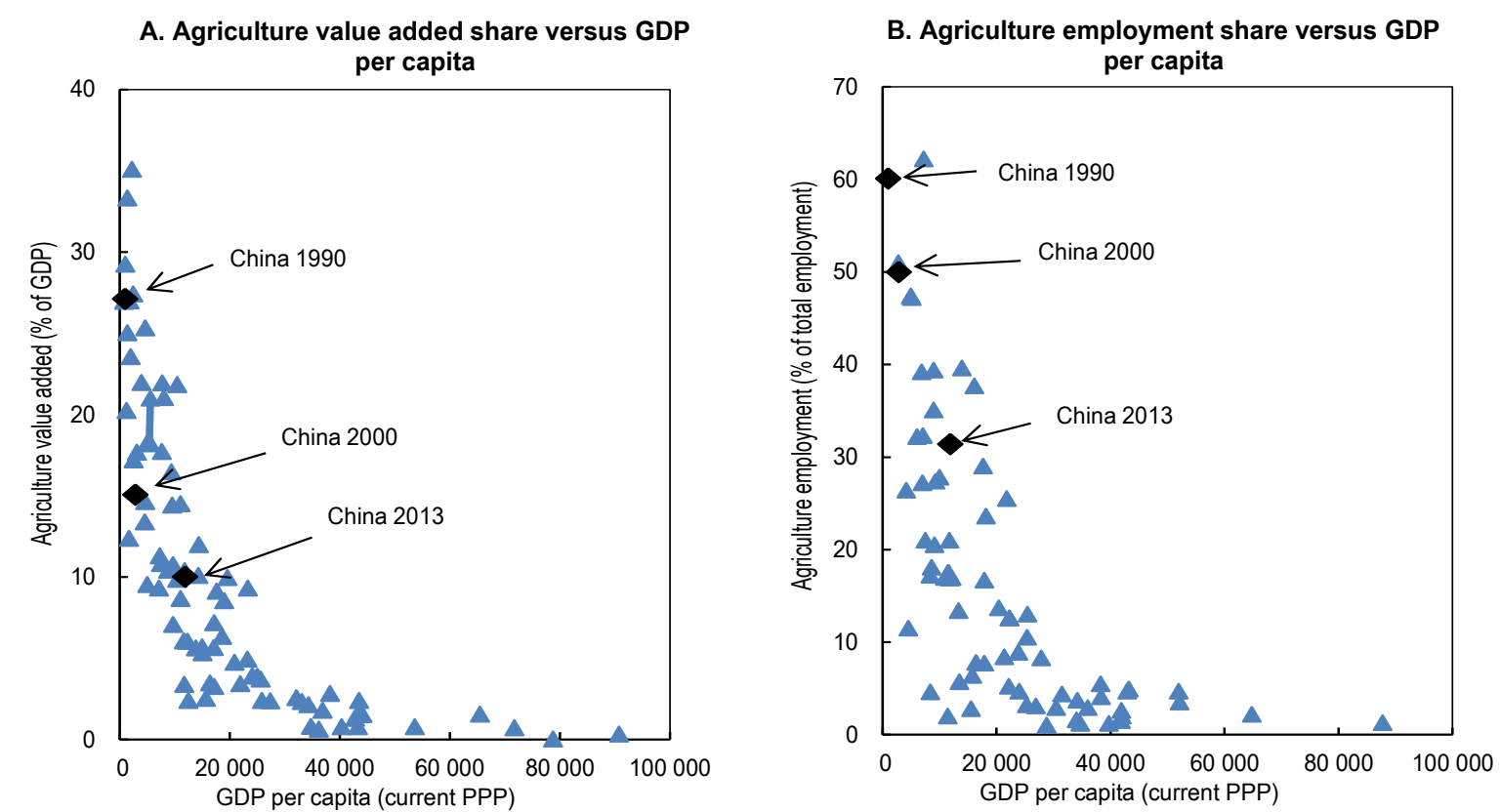

Note: Figures relate to all countries for which comparable data are available. Unless specified, data in Figure A are for 2013 and data in Figure B are for 2012.

Source: World Bank World Development Indicators.

1. Ben Westmore (ben.westmore@oecd.org) is a member of the OECD Economics Department. This paper is based on Chapter 2 of the OECD Economic Survey of China published in March 2015 under the authority of the Economic and Development Review Committee (EDRC). The author would like to thank Alvaro Pereira, Robert Ford, Vincent Koen, Margit Molnar, Andrzej Kwiecinski and colleagues from the OECD's Trade and Agriculture Directorate, Directorate for Public Governance and Territorial Development, Directorate for Employment, Labour and Social Affairs, Directorate for Science, Technology and Industry and Environment Directorate for valuable comments on earlier drafts. The paper also benefitted from the comments of officials from the Chinese government. Special thanks go to Thomas Chalaux and Clara Garcia for statistical support and Nadine Dufour and Mercedes Burgos for editorial assistance. 
added above $10 \%$ compared with 1-2\% in developed economies, and its share in employment at around $35 \%$ as against 2-3\% (Koen et al., 2013). The scale of the ongoing transition is highlighted by government plans to grant urban residential status to 100 million rural migrants by 2020 . This structural adjustment process can deliver substantial opportunities for the rural economy and China as a whole, but entails major challenges calling for continued reform efforts.

3. At the centre of this rural adjustment process are agricultural producers who either wish to continue to farm or who realise their skills could yield a higher marginal product if employed elsewhere. Indeed, as the rural sector develops, farmers are faced with the choice of raising farm productivity or reallocating their resources to allow other farmers to scale up operations. Enabling the latter process is particularly important in China, as historical land assignment practices have resulted in a high proportion of small farming operations relative to other middle-income countries.

4. Figure 2 sets out the development pathways facing farmers and the government policy areas that are important for facilitating the transition of the rural economy. Following the experience of other middleincome and OECD countries, farmers commonly follow alternative routes during the adjustment phase: i) stay working the farm and raise productivity, ii) transition away from agriculture to pursue off-farm employment, or iii) discontinue operating their farmland without taking up employment elsewhere (usually the elderly and less able). Many policy dimensions come into play, going well beyond agricultural policies per se.

5. This paper first focuses on different aspects of the rural economy that need to be addressed by policymakers to promote productivity gains in China's agricultural sector. These will include measures that benefit the transition of agricultural workers to other work opportunities either within or outside agriculture. The paper then turns to government policies providing income support to rural citizens and recommends some reforms that would further ease the rural adjustment process. The main findings include:

- Farm size is very small in the agricultural sector, limiting the scope for mechanisation and economies of scale. Furthermore, poorly defined land contract rights and incomplete markets for the transfer of land operation rights impede farm consolidation. This may hamper the government's ability to continue achieving food security objectives (Box 1).

- Rural residents aspiring to move to cities with the greatest economic opportunities continue to face policy constraints, slowing the rural adjustment process.

- For those wishing to remain in rural areas, social welfare coverage is incomplete and health services lag significantly behind those in urban China. In many cases, labour mobility is impeded by a lack of portability of health insurance benefits outside the local area.

- Further investment in public infrastructure such as transport, electricity and information technology (IT) networks will be important for enabling agricultural producers to lift productivity and to connect rural citizens wishing to pursue off-farm work or education with desirable locations.

- Many rural citizens have difficulty accessing finance partly because poorly defined land contract rights limit collateral.

- China's arable land per capita is low relative to other countries and the sustainability of farming continues to be threatened by overuse of chemical fertilisers, relatively poor water efficiency and degradation of grassland. 
- As Chinese agriculture continues to modernise, farmers need the skills to translate new technologies into productivity gains. Farmer skills are also important to adapt production as consumer demand patterns shift away from traditional grains with rising household incomes.

Figure 2. Government policies are critical in facilitating rural development

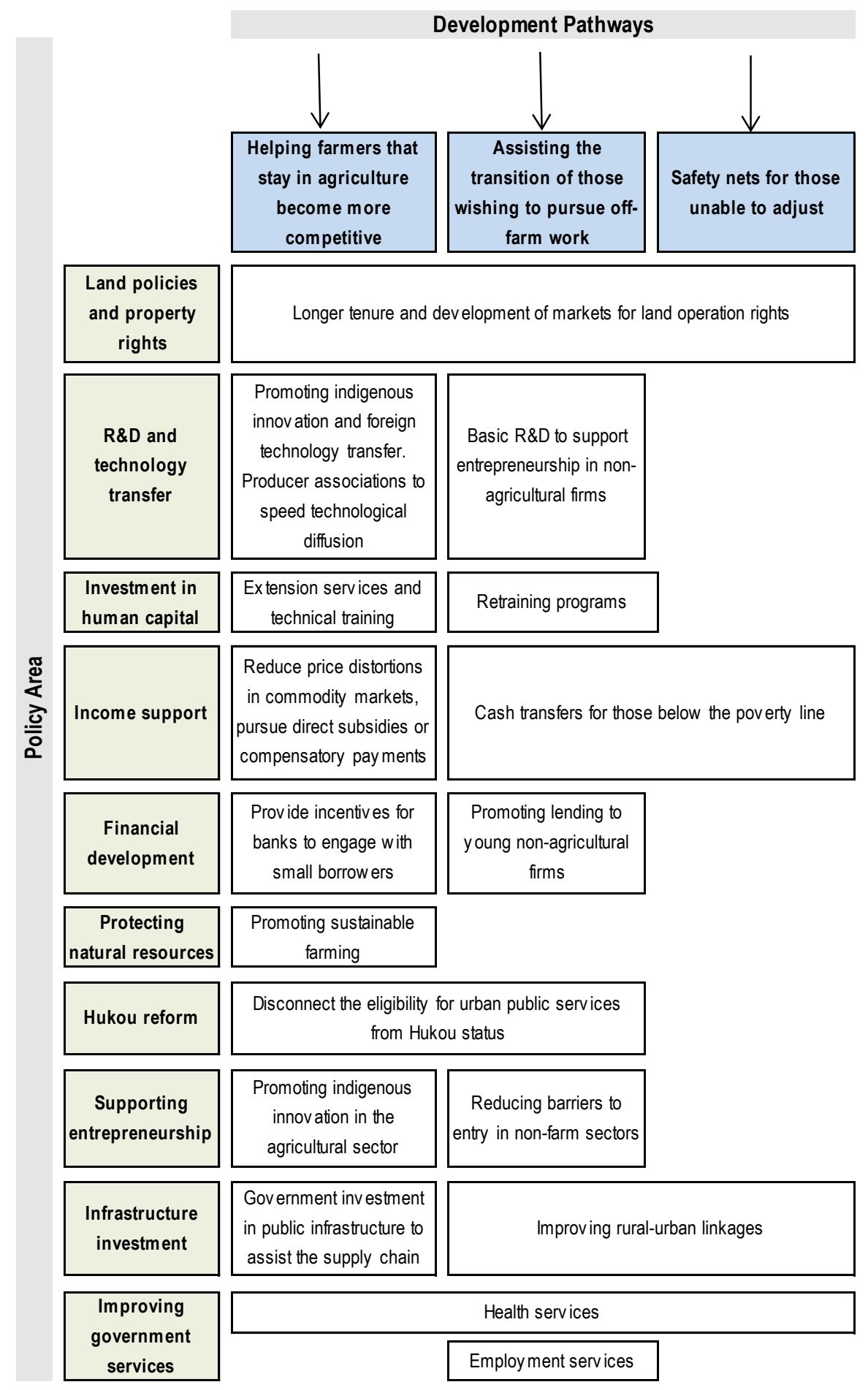

Source: Adapted from Cervantes-Godoy and Brooks (2008). 


\section{Box 1. Food security}

With still vivid memories of famine and in the wake of the 2007-08 global food price spike, food security remains a key government priority in China. The Food and Agriculture Organisation of the United Nations (FAO) defines food security as the ideal in which all people, at all times, have physical, social and economic access to sufficient, safe and nutritious food to meet their dietary needs and food preferences for an active and healthy life. The task may be particularly challenging in China: it has around $20 \%$ of the global population with just $10 \%$ of the world's agricultural land and below average water resources per capita. Moreover, the government is committed to a high level of agricultural self-sufficiency. This has led to some specific policy measures including a "red line" for farmland to remain above 120 million hectares, government purchases of food reserves to encourage domestic production and an objective for $95 \%$ grain self-sufficiency.

Government reserves of various commodities can provide a buffer in the case of food shortages. The accumulation of reserves is administered by government bodies such as the China Grains Reserves Corporation or commercial enterprises that have storage and operation costs subsidised by the government (Table 1). The responsible government department varies depending on the particular commodity. In addition to ensuring food security, reserves are used to reduce price volatility in agricultural markets, limiting spikes in food prices for consumers and fluctuations in farm incomes. Purchases for some commodities, such as grains, are a product of the minimum price policies of the government (discussed further below). For other commodities, reserves are accumulated on an ad hoc basis, usually during times of falling prices. While data on the size of government reserves are not publicly available, they are estimated to be significant for some commodities (Zhou, 2010). A downside to these purchases is that they distort market signals and may encourage illegal imports by inflating domestic prices relative to international prices. Furthermore, storage facilities can entail high costs to build and operate, with continued rotation of stock important for reducing potential storage losses from infestation or moisture damage.

Table 1. China maintains reserves of various food commodities

\begin{tabular}{|c|c|c|c|}
\hline Commodity class & Varieties & $\begin{array}{c}\text { Government department } \\
\text { responsible }\end{array}$ & Storage entities \\
\hline Meat & $\begin{array}{l}\text { Beef, mutton, pork and live } \\
\text { animals }\end{array}$ & $\begin{array}{l}\text { Ministry of Commerce } \\
\text { (MOFCOM) }\end{array}$ & Commercial enterprises \\
\hline Sugar & & MOFCOM & Commercial enterprises \\
\hline Grains & $\begin{array}{l}\text { Raw grains, wheat, rice, } \\
\text { corn, maize, soybeans, } \\
\text { rapeseed and wheat flours }\end{array}$ & $\begin{array}{l}\text { National Development and } \\
\text { Reform Commission (NDRC) }\end{array}$ & $\begin{array}{l}\text { China Grains Reserves Corp. of the } \\
\text { central government and the grain } \\
\text { storage enterprises of the provincial, } \\
\text { municipal and county-level } \\
\text { governments }\end{array}$ \\
\hline Cooking oil & & NDRC & $\begin{array}{l}\text { China Grains Reserves Corp. of the } \\
\text { central government and the grain } \\
\text { storage enterprises of the provincial, } \\
\text { municipal and county-level } \\
\text { governments }\end{array}$ \\
\hline Cotton & & NDRC & $\begin{array}{l}\text { China National Cotton Reserves } \\
\text { Corp. of the central government and } \\
\text { the cotton storage enterprises of the } \\
\text { provincial, municipal and county- } \\
\text { level governments }\end{array}$ \\
\hline Salt & & NDRC & $\begin{array}{l}\text { China National Salt Industry Corp. of } \\
\text { the central government and the local } \\
\text { salt corporations of the provincial, } \\
\text { municipal and county-level } \\
\text { governments }\end{array}$ \\
\hline Tea & & MOFCOM & Commercial enterprises \\
\hline
\end{tabular}

Source: China Merchandise Reserves Management Centre, China Grain Reserves Corporation, China National Cotton Reserves Corporation, China National Salt Industry Corporation and Ministry of Commerce.

The government's pursuit of food self-sufficiency partly reflects a wariness of the potential impact on global prices if a country as large as China were to increasingly rely on international markets for food supply. Nevertheless, since China's entry into the World Trade Organisation (WTO) China has sourced more agricultural products from abroad. In particular, net imports of vegetable oils, oilseeds, cotton, sugar and milk products have picked up (OECD-FAO, 2013). This has coincided with a change in the government's self-sufficiency policy to emphasise the importance of "absolute self-sufficiency" in the two staple food grains - wheat and rice, while allowing more flexibility in the production of other grains (OECD-FAO, 2014). 


\section{Achieving further productivity gains in the agricultural sector and the non-agricultural rural economy}

6. Some country-specific factors have shaped China's rural development process. In particular, reforms that began in the early 1980s have played a big role, including the introduction of the household responsibility system (which allowed farmers to profit from their land allocation even though land remained collectively owned), the gradual abolition of taxes and fees on agricultural production and strong government investment in rural public infrastructure. Accordingly, total factor productivity (TFP) growth in agriculture picked up sharply, contributing to stable agricultural output growth over the past few decades (Figure 3).

Figure 3. Reforms have boosted agricultural growth Annual percentage change
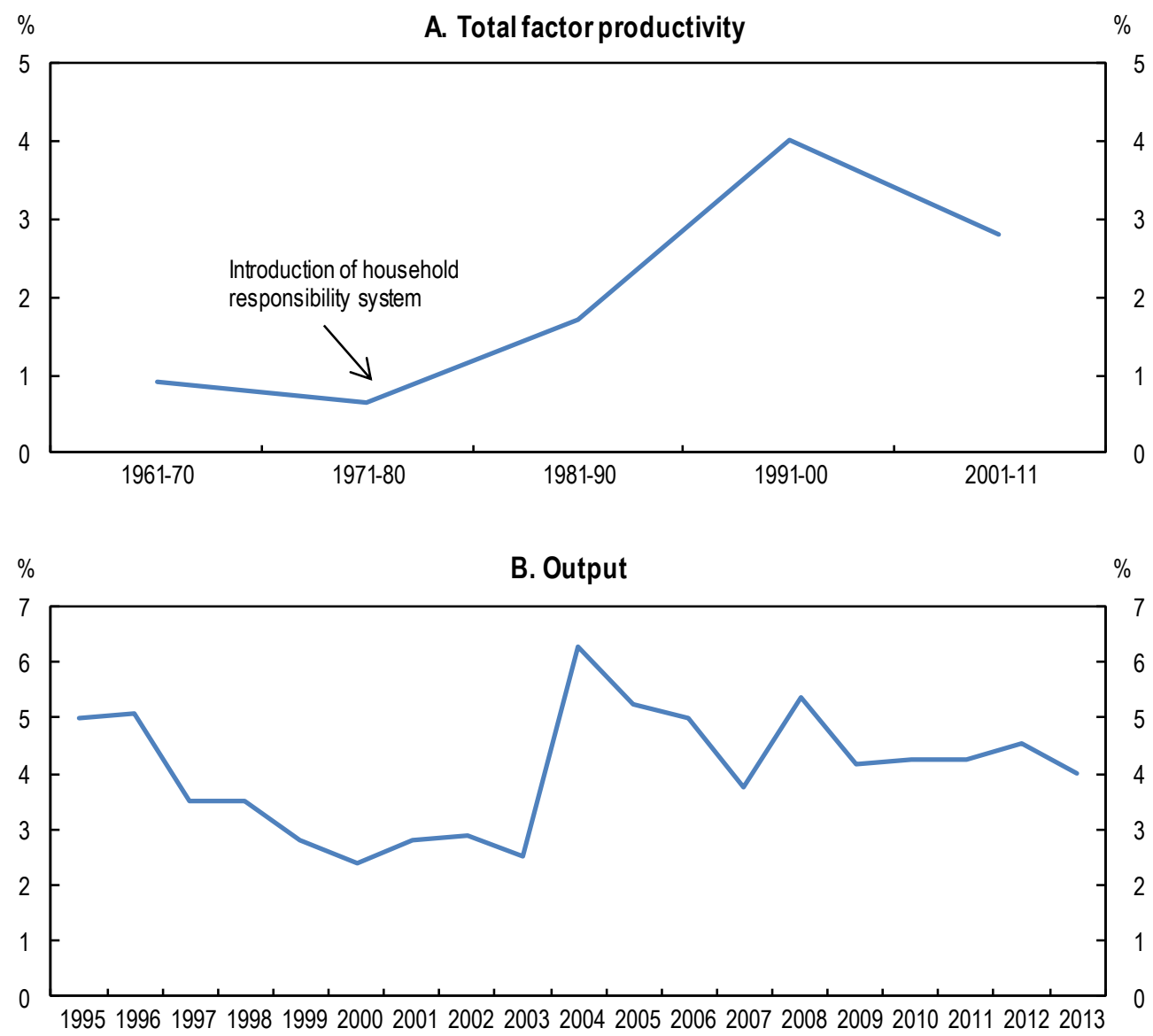

Note: TFP is calculated using FAO gross agricultural output smoothed with a Hodrick-Prescott filter. Input growth is the weightedaverage growth in quality-adjusted land, labour, machinery power, livestock capital, and synthetic three-component fertilisers, where weights are input cost shares (Fuglie, 2012). Measurement issues with this TFP measure have been identified (Alston and Pardey, 2014), suggesting caution in drawing strong conclusions based on these data.

Source: US Department of Agriculture, CEIC.

7. While land productivity is relatively high in China's agricultural sector, labour productivity remains low compared with other countries at a similar stage of development (Figure 4). This is despite recent increases in the land-to-labour ratio with rising emigration to urban areas: the number of rural-urban migrants totalled 270 million by 2013 and the land-to-labour ratio rose by $50 \%$ between 1990 and 2010 according to some estimates (Fuglie, 2012). Looking forward, further productivity gains can come about 
through a variety of channels. The policy reforms that can contribute in this regard are now discussed in turn.

Figure 4. Compared with other middle-income countries, agricultural labour productivity is low Average level 2006-11
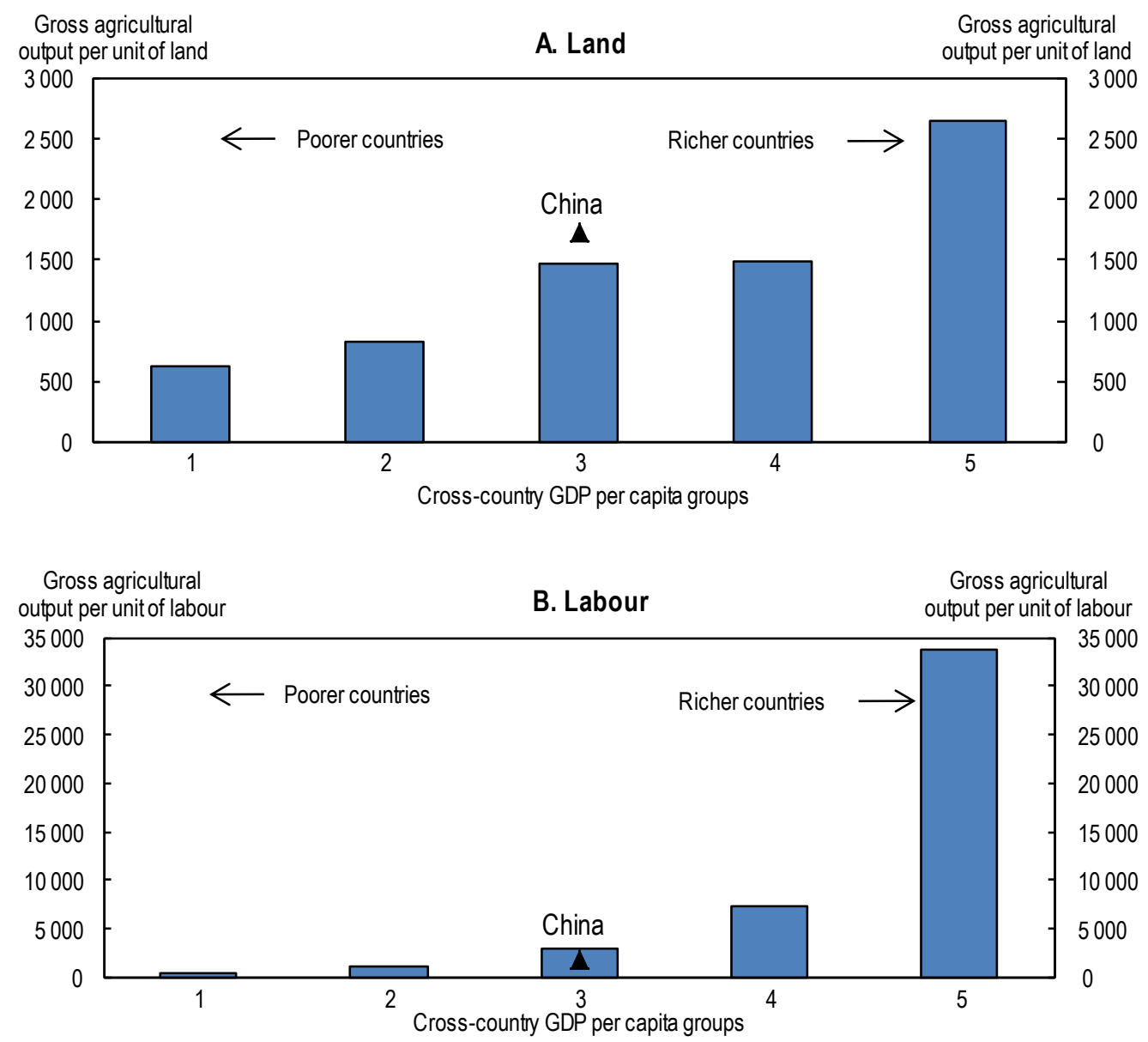

Note: GDP per capita groups are calculated as averages based on data for 132 countries. Gross agricultural output is measured in constant 2005 US dollar terms, the land input is the number of hectares adjusted for quality and labour is the number of economically active persons working in agriculture (Fuglie, 2012).

Source: US Department of Agriculture, authors' calculations.

\section{The land-tenure system constrains farm consolidation and the mobility of rural workers}

8. Rural land in China is owned collectively at the village or sub-village level and is usually classified as either farmland or construction land. While farmland is exclusively used for agricultural purposes, construction land is collectively-owned rural land for non-agricultural use such as housing. The government seeks to promote larger-scale farms (Central Committee of the Communist Party and the State Council, 2015). To fulfil this goal, measures to foster the development of markets for the transfer of rural land rights and improvements to the model for local government funding are key (recent revisions to the budget law that entitle local governments to issue municipal bonds are a step in this direction). 


\section{Farmland contract rights are poorly defined and tenure length is too short}

9. At the time of the introduction of the household responsibility system, rural households received rights to an allocation of farmland from the village collective. The size of the land allocation was generally based on household size or labour supply, with land use restricted to agricultural purposes. Initially the contracts were granted for five years, before being extended to 15 years in 1984 and 30 in the late 1990s. Reflecting differences in fertility, location and irrigation, each household was assigned a number of noncontiguous land plots of varying quality. The average household received rights to three or four separate plots with some households holding the rights to as many as ten (Huang et al., 2012). While aiming for an equitable distribution of land assets, this practice has raised a number of issues for agricultural production. First, the high degree of fragmentation in farm holdings has limited mechanisation and the extent to which economies of scale can be realised. Second, poorly-defined contract rights and incomplete markets for the transfer (or "circulation", in the domestic terminology) of the operation rights to farmland have constrained agricultural productivity gains. Third, the limited tenure of contracts to farmland may weaken farmers' incentives to invest in sustainable farming practices.

10. The average farm size (where a farm is defined as a continuous tract of agricultural land) in China is small compared with other middle-income countries (Table 2). While the optimal farm size will depend on various elements including topography and production mix, some farm consolidation may improve the scope for mechanisation and vertical integration of production. With significant increases in farm wages over recent years, the incentives for substituting capital for labour have risen (Wang et al., 2014a). Some of the benefits of consolidation have been captured through strong growth in farmer professional cooperatives and equipment rental services in China. However, individual farmers could reap substantial efficiency gains from being able to consolidate fragmented land into larger plots.

11. The promotion of large-scale farming has advanced in some provinces, especially for livestock (Huang et al., 2012). Heilongiiang, the province with the greatest area of cultivated land per capita, has been the focus of a government pilot programme that gives subsidies to farmer cooperatives that consolidate at least 5000 acres (2 023 ha) of arable land. By 2012, China had 2.7 million farms above $100 \mathrm{mu}(6.67 \mathrm{ha})$. Nevertheless, this is equivalent to just $1.4 \%$ of the total number of Chinese farms identified in the 2006 agricultural census (Gale, 2013).

Table 2. Average farm size is small in China

\begin{tabular}{lc}
\hline & Average farm size (ha) \\
\hline China & 0.6 \\
Vietnam & 0.7 \\
Indonesia & 0.8 \\
Japan & 1.2 \\
India & 1.3 \\
Thailand & 3.2 \\
Turkey & 3.2 \\
Columbia & 25 \\
Venezuela & 60 \\
Brazil & 73 \\
Chile & 84 \\
South Africa & 288 \\
\hline
\end{tabular}

Note: Data for comparison countries are from agricultural censuses between 1996 and 2005. Data for China are for 2010. Source: 2000 FAO World Census of Agriculture, Huang et al. (2012). 
12. More important than merely increasing average farm size is enabling the most productive farmers to scale up their operations. Ideally this will occur through the reallocation of farmland from those farmers who are less productive or have a high opportunity cost of farm production. The optimal mechanism for land reallocation is through a well-developed institutional structure that allows operation rights to be transferred between farmers. However, in China, the absence of such a mechanism has impeded the mobility of rural citizens or led to deserted plots of agricultural land as farmers emigrated elsewhere. Still, arrangements are evolving whereby farmers rent out operating rights while retaining the contractual rights to farmland, and promoting land transfer is among the priorities set out by the Third Plenum. This provides the farmers who wish to emigrate to cities, pursue other rural work opportunities or retire in the rural area an income stream without forcing them to surrender their rural rights altogether. Some areas, such as Henan Province, have gone a step further by exploring the possibility of farmers transferring their contractual rights for monetary compensation. However, at this stage, the transfer of operation rights is the more common tool for land consolidation.

13. With increasing encouragement from the central government and new instruments, such as joint land-stock cooperatives and land circulation trusts (Box 2), the transfer of operating rights has steadily risen over the past two decades (Figure 5). This has been particularly the case in coastal areas where offfarm work opportunities have been plentiful (Hoken, 2012). Nevertheless, the intensity of land transfer in China remains below that in advanced countries.

14. Some farmers are hesitant to rent out their land because their contract rights are poorly defined. There are significant differences across provinces, with a 2009-10 survey finding that while only 33\% of households in Jiangxi province held a land certificate, 97\% did in Gansu province (Ma et al., 2015). The government commenced a pilot programme in 2008 to provide certification of farmland contract rights to households, with 100 counties taking part by 2013 . There are also some pilot programmes underway to use satellite technology combined with village records to identify and enforce property boundaries. The government aims to complete the process of assigning land-right certificates to rural households by 2020 . If completed, this is a major advance, which will reduce transaction costs of land transfer and allow those households wishing to pursue off-farm work to do so without fearing they will lose their farmland entitlement.

15. Farmers wishing to rent out land have also been held back by a perceived lack of contract enforcement by independent courts and corruption of local officials (Lohmar, 2013). Land contract insecurity has been identified as a constraint to land rental and the migration of rural households toward better economic opportunities (Giles and $\mathrm{Mu}, 2014$ ). In late 2014, the Fourth Plenum of the 18th Chinese Communist Party Central Committee emphasised the importance of the rule of law and law enforcement is to be added to the indicators used to evaluate local government officials' performance. Further reforms that improve contract enforcement will be a necessary complement to better defined contract rights for promoting the reallocation of rural land. 
ECO/WKP(2015)36

Figure 5. The proportion of rented farmland has increased but remains below advanced countries

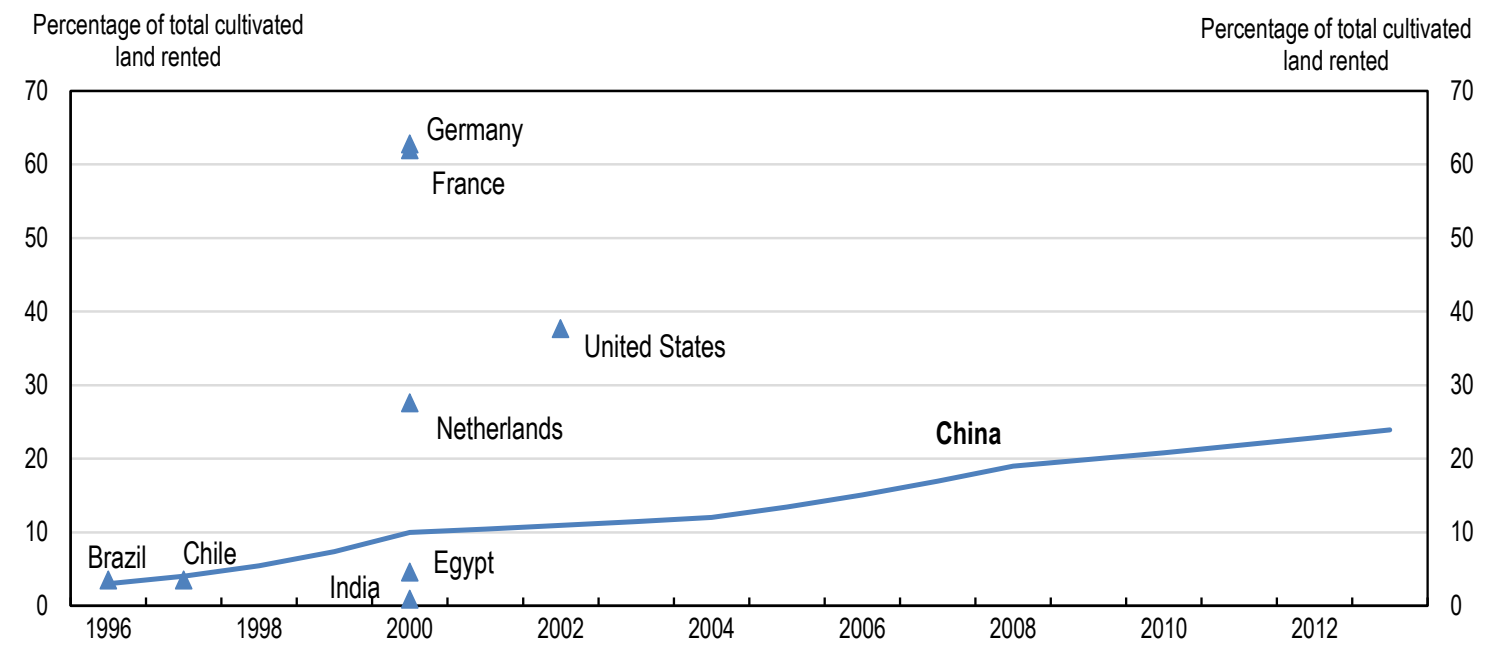

Note: The figure shows that the share of rented cultivated farmland in China increased from 3\% in 1996 to around $24 \%$ in 2013 . Estimates from the World Census of Agriculture highlight that China's share of rented farmland by 2013 remained below point estimates for many developed economies taken around 2000. These included France (taken in 2000), Germany (2000), the US (2002) and the Netherlands (2000).

Source: 2000 FAO World Census of Agriculture, Gao et al. (2012), State Council of the People's Republic of China.

\section{Box 2. The development of China's land rental market}

China's rural land tenure system has resulted in unique arrangements for transferring land (Research Institute of Economy, Trade and Industry, 2014). There are five main types of arrangements:

i. Exchange of land-use rights - Within the same collective, two farmers may want to exchange operation rights for their respective land. This may aid consolidation for farmers who have a number of noncontiguous plots.

ii. Leasing of operation rights - In such an arrangement, farmers rent out the right to cultivate their land to another entity within or outside the rural collective (however, under equal conditions, members from the collective are given priority). Despite renting out the operation rights, the farmers retain the contract right to the farmland.

iii. Outright transfer of contract rights - Conditional on the lessor having built a stable livelihood outside the agricultural sector, the outright transfer of contract rights is allowed. At this point, the contract between the household transferring out the land and the village is terminated (Ma et al., 2015).

iv. Land joint-stock cooperatives - Farmers may jointly pool their operation rights to engage in cooperative agricultural production. They are then given a share of the joint-stock cooperative and are generally paid a dividend proportionate to their share. The three major types of joint stock cooperative arrangements are (Chang et al., 2012):

1. "Community type" where a group of farmer households pool their rights and undertake unified planning, production, operation and management of the land.

2. "Collective leasing type" where farmers entrust the operation rights to a collective cooperative which then may re-organise the land before issuing it for public lease.

3. "Joint operating type" where farmers transfer shares to a rural land joint-stock company, which is often a larger agricultural enterprise with modern technologies and skills. Farmers retain a share of the profits derived from the land.

v. Land circulation trusts - Farmers entrust their operation rights to a trust company, which is responsible for finding tenants, land development, procuring funds and organising construction activities (Figure 6). Some of these functions, such as land development and recruitment of tenants, are undertaken by an operating 
company contracted by the trust. The first such trust was CITIC Trust Co., Ltd which was established in 2013 in Yongqiao district, Suzhou, Anhui province. As part of this arrangement, in return for their operation rights, farmers receive rent and a share of the net profits of the trust (dependent on the area of land they initially contributed). Farmers may obtain a further income stream through working as employees of the operation.

Figure 6. Operation of a land circulation trust

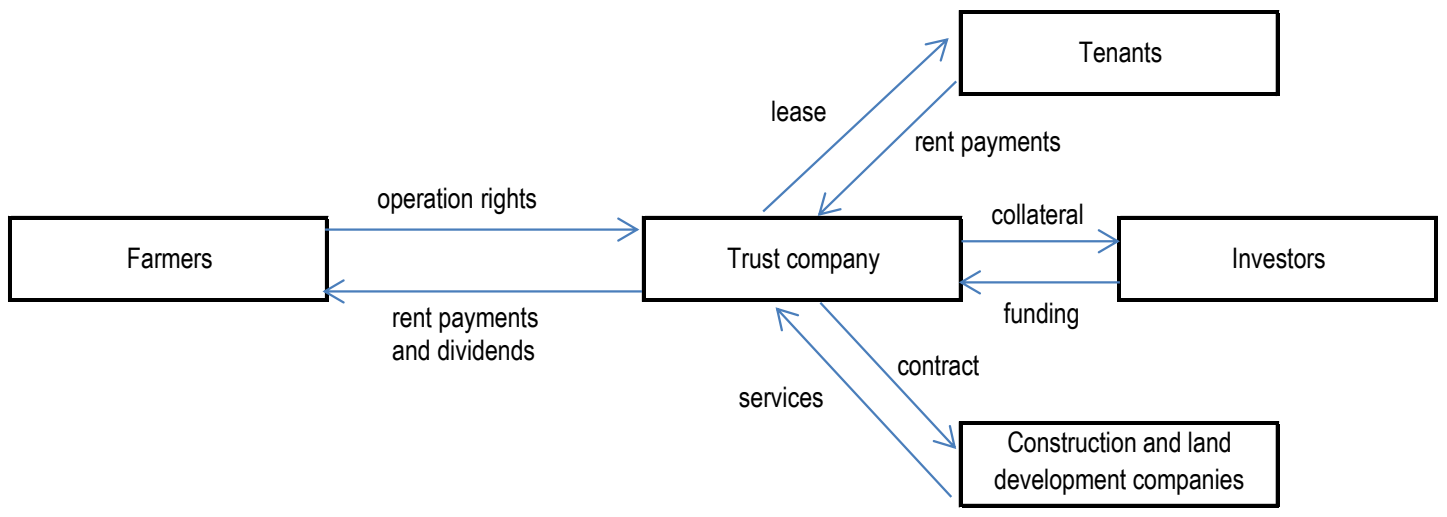

Source: Research Institute of Economy, Trade and Industry, 2014.

16. Land transfer is also hindered by the difficulty of valuing operation rights: markets for exchanging operation rights lack transparency and there is no uniform method for valuing rights. Indeed, household surveys suggest significant mismatches between the price expectations of those wishing to rent in and those wanting to rent out operation rights to farmland (Khantachavana et al., 2013). Alongside the planned provision of documented contract rights to all farmers, land transfer will be assisted by continued efforts to establish well-regulated, transparent, exchange platforms that intermediate the transfer of operation rights. The government recently issued guidance outlining the desirable characteristics of exchange platforms for rural assets. They advised that exchange platforms should be established by nonprofit institutions (public or otherwise), be internet-based and cover a variety of assets (e.g. operation rights to rural land, rural collective operating assets, agricultural production facilities and use rights for water conservation facilities). Exchanges should also aim to provide various services such as asset valuation, legal advisory and assistance in connecting households with land-backed mortgage financing.

17. While continued development of land rental markets is important for facilitating the rural adjustment process, it could limit investment in sustainable farming practices. Central government law stipulates that the term of the transfer contract for operating rights must not exceed the term of the contract rights. Given that the tenure for contract rights is just 30 years, a farmer renting in land will only be able to guarantee they will be cultivating the area for a limited period of time. This may lower the incentive to undertake farming practices that ensure the long-term fertility of the plot. For example, farm level analysis suggests that there is a significant decrease in the use of organic manure when farmers rent in land (Gao et al., 2012). In general, contract duration for farmland is lower than for urban land which is 70 years for residential land, 50 years for industrial land and 40 years for commercial, tourism or recreational land (World Bank and DRC, 2014). The 2008 and 2013 third plenums have suggested that rights to farmland should be for the "long term without change". This marks important progress. However, no provision has yet been written into law. 


\section{Rural construction land rights are still not fully tradable}

18. While also under collective ownership, rural construction land - classified as either commercial or residential - is more strictly controlled by the government. Although the November 2013 Third Plenum announced the government's intention to end restrictions on the transfer of use rights to rural construction land, this appears to only apply to land for commercial purposes (Yuen, 2014). The authorities recognise the benefit of establishing secure and tradable residential property rights, but at this point such transfers are confined to a few pilot programmes.

19. Rural residential land is intended to be used for farmers to build their residences. The stock of such land is almost twice as large as existing urban land and can be developed without the stringent conditions that exist for the conversion of farmland (World Bank and DRC, 2014). Such land is relatively valuable and, when located on urban fringes, has been prone to expropriation by local governments that convert it to urban land before transferring the use rights to property developers. This practice has proven to be a critical source of revenue for local governments in the face of a rising gap between their expenditures and the revenue transfers they receive from the central government. In the process, farmers are compensated, but the compensation is often meagre compared with the full value of the construction land (OECD, 2015). This has led to episodes of social unrest. Indeed, some estimates suggest that $65 \%$ of social conflicts in China's rural areas involved disputes over land (Yuen, 2014). Consequently, reforms that buttress contract rights to rural construction land and reduce local government land expropriations will need to be coupled with measures that ensure local governments have sufficient other sources of revenue to be fiscally sustainable (Wang and Herd, 2013).

20. In Chengdu and Chongqing there is currently a scheme whereby, in return for converting their residential construction land to farmland, rural residents obtain a dipiao (land ticket). The latter can be sold via a property exchange to developers, entitling them to convert farmland zoned for development in urban areas where demand is high. This approach is supposed to meet multiple objectives of the central government: expanding the housing infrastructure for new urban migrants and the income sources of farmers in rural areas and ensuring that the volume of China's arable land does not fall below the government's "red line" of 120 million hectares. Nevertheless, some farmers claim they have been forced to convert ancestral homes against their will or have not received compensation from the property exchange for the sale of a dipiao. In 2010, the State Council documented these problems and urged local governments to step up surveillance of the schemes and punish actions that compromised farmer's interests (State Council, 2010).

\section{Hukou reform will improve the reallocation of labour resources}

21. Removing barriers to migration can complement land reforms in promoting the rural adjustment process. Economic considerations appear to have been a key driver of the pattern of migration in China over recent years (Figure 7). Between 2005 and 2010, the top five provinces in the average wage distribution were the destination for over $65 \%$ of China's migrants. Nevertheless, China's household registration system (hukou) discriminates against rural workers who would like to move to urban areas for off-farm work opportunities. This is because migrants who retain their original hukou typically have restricted access to services where they work, notably with respect to education (Molnar and Koen, 2015), health care, pension, welfare and affordable housing. Indeed, despite improvements over recent years, migrant workers still have very low social insurance coverage rates, with only $18 \%$ possessing medical insurance (Table 3). In addition, in 2013, over half China's migrant workers did not have an employment contract and the majority of those that did had a fixed-term one. The hukou system may also disadvantage firms in rural areas where a lack of suitable local labour holds back growth. In addition, the system may exacerbate urban-rural inequalities by limiting urban migration and the subsequent flow of remittances to rural areas. 
Figure 7. Provinces with a high relative wage have attracted migrants

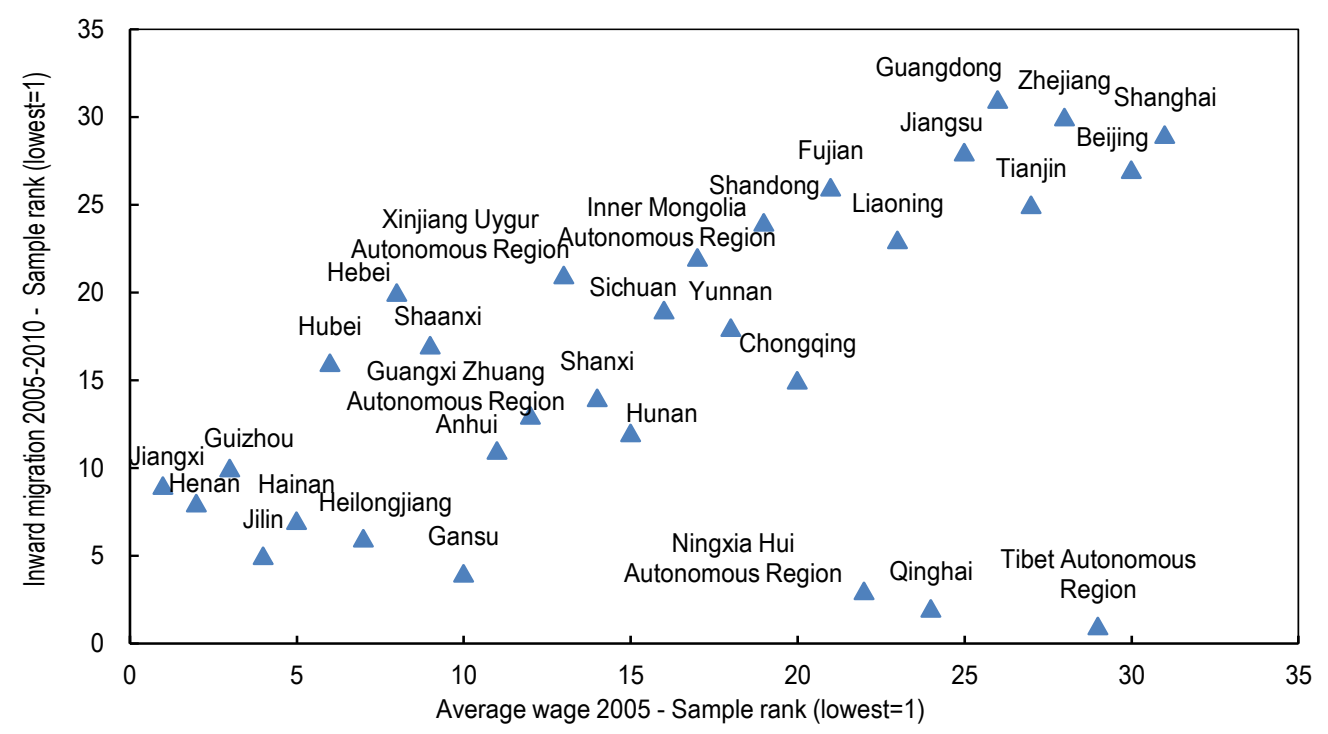

Source: China Statistical Yearbook 2006, 2010 Census of China, authors' calculations.

Table 3. Migrant workers have limited access to public services

In per cent

\begin{tabular}{|c|c|c|c|c|c|c|}
\hline & 2008 & 2009 & 2010 & 2011 & 2012 & 2013 \\
\hline \multicolumn{7}{|l|}{ Social insurance coverage } \\
\hline Pension & 10 & 8 & 10 & 14 & 14 & 16 \\
\hline Industrial injury insurance & 24 & 22 & 24 & 24 & 24 & 29 \\
\hline Medical insurance & 13 & 12 & 14 & 17 & 17 & 18 \\
\hline Unemployment insurance & 4 & 4 & 5 & 8 & 8 & 9 \\
\hline Maternity insurance & 2 & 2 & 3 & 6 & 6 & 7 \\
\hline
\end{tabular}

Source: National Bureau of Statistics.

22. Recent government reforms are welcome, such as removing restrictions on the transfer of hukou status in small cities and relaxing the regulations in medium-sized ones. A major novelty was the guidance that rural residents converting their hukou would retain their contract rights to rural land. In the past, the prospect of losing rural land rights may have discouraged migration (OECD, 2013a). Nevertheless, restrictions remain stringent for migrants to large (3-5 million people) and megacities (above 5 million people), where productivity and wages are highest. In these areas, eligibility for hukou is dictated by a points-based system that favours long-time residents and those with high levels of education and skills. Further reforms should focus on disconnecting the eligibility for urban public services from hukou status. This may be achieved by introducing residency permits that allow the holder to access public services, while retaining a system that protects the land entitlements of migrants. Since 2011 the prefecture of Suzhou has established a residency permit system along these lines, with almost full coverage of the entire migrant population (OECD, 2013a). Evaluations of the programme highlight effective electronic information management systems as particularly important for enabling local authorities to keep track of the resident population and provide public services (Ding and Lin, 2013). 
23. One significant challenge to hukou reforms is cost. Absent significant new investments, the provision of resident permits to all migrants would place public services in many urban areas under considerable stress. In the context of the current fiscal system, such reforms would require transfers from the central to local governments in proportion to the increased coverage of public services they must provide. An alternative is that funding could partly derive from subnational governments, but this would need to be coupled with tax reforms that boost subnational government income such as a possession-based rather than a transaction-based property tax (OECD, 2013a).

\section{A lack of rural financial development is hampering efficient resource allocation}

24. Difficulty in accessing finance in rural areas may impede the reallocation of resources to high-potential agricultural operations. Even if farmers manage to scale up their land holdings through renting in operating rights to farmland and attract suitable labour, poor access to finance may limit farm investment and mechanisation. A large problem for farmers in many developing countries is a lack of collateral. This is particularly pronounced in China due to the land tenure system and the fact that contract rights are not well defined and tenure is limited. Furthermore, property law forbids the contract rights to rural land to be mortgaged. The 2009 OECD Rural Policy Review of China emphasised the importance of continued reforms that improve the availability of finance in rural areas (OECD, 2009). While progress has been made, rural financial development should remain a policy focus.

25. The rural financial system has gone through significant restructuring over recent years. Rural credit cooperatives - the dominant lending institution since the pre-reform period - are being gradually restructured and those with better asset quality transformed into rural commercial banks and rural cooperative banks. While not the case for rural commercial banks, rural credit cooperatives are obliged to allocate a certain share of their loan portfolios to agricultural projects (Ong, 2013). In addition, China Postal Savings Bank, an institution with more than 39000 branches nationwide and a considerable rural network, has been allowed to issue loans since 2007 and has also introduced various microloan schemes. These developments have contributed to solid growth in lending to the agricultural sector, with the combined real assets of the major rural lending institutions tripling since 2005 (Figure 8).

Figure 8. Lending to the rural sector has expanded significantly

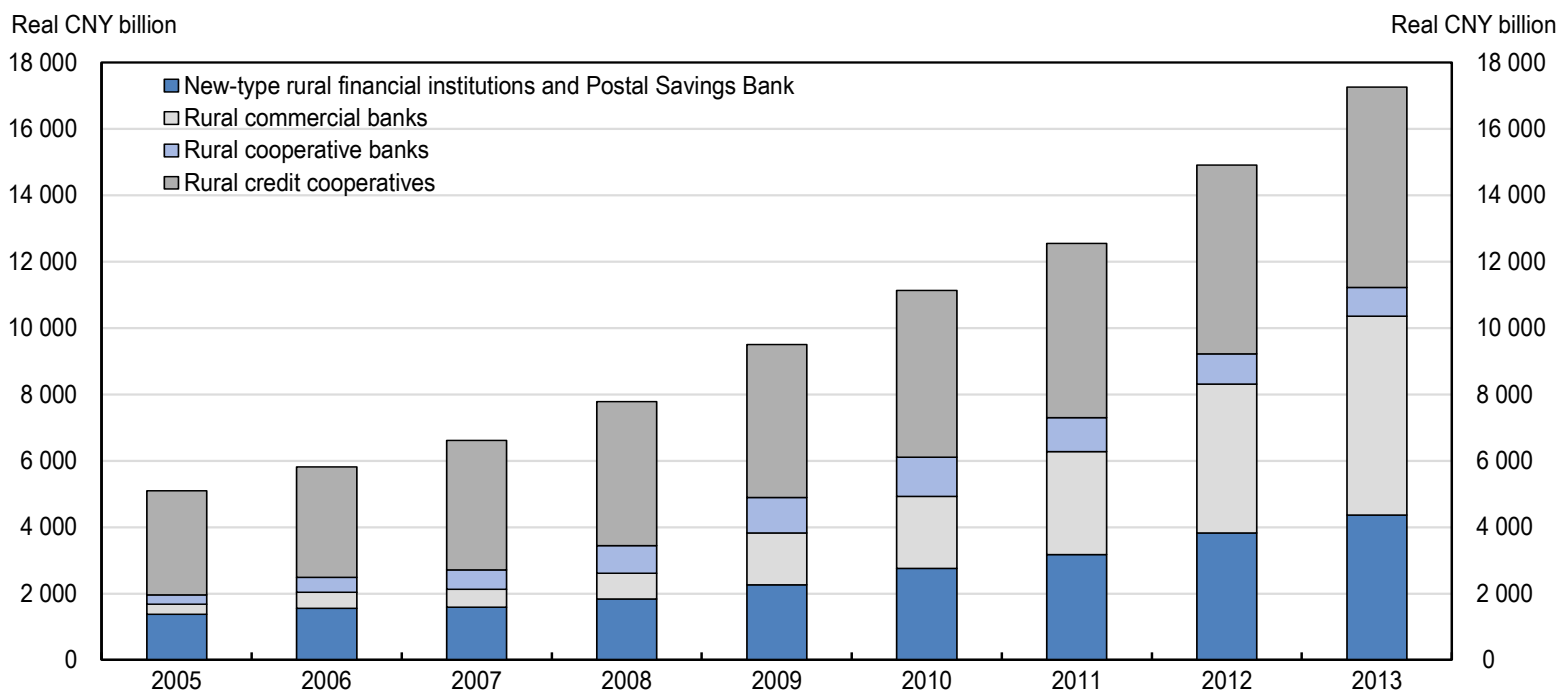

Note: Nominal values are deflated by the GDP deflator, with 2005 as the base year.

Source: China Banking Regulatory Commission Annual Report 2013. 
26. Nevertheless, lending by these institutions is currently biased toward larger, usually state-owned, enterprises that have significant collateral and guarantees. Regulatory restrictions discourage non-secured lending and many financial institutions are not willing to incur the higher transaction costs involved in accessing farmers or to accept the non-standard attributes often characterising farmers' collateral (Duflos and Ren, 2014; World Bank, 2011). This environment may not only limit the ability of small-scale farmers to scale up production, but also the mobility of those agricultural workers who require finance in making the transition into off-farm work.

27. For small-scale farmers, government incentives that encourage "branchless banking" practices which lower transaction costs, and perhaps lower collateral requirements, should be introduced. For those transitioning away from agriculture, the presence of institutions offering microcredit (small loans for individuals with limited formal collateral) may be important. While the Chinese government has promoted this type of finance through establishing a new form of licence for microcredit companies, regulatory restrictions on these firms are tight. For example, microcredit companies cannot accept customer deposits and are not allowed to have a debt-to-equity ratio above 50\%, which is very low by international standards. In addition, the central government sets high minimum capital requirements, with most provinces requiring an additional capital buffer (Geraci et al., 2010). Such regulations reduce the profitability of microcredit companies and their capacity to expand credit supply.

\section{Box 3. Contract farming}

Contract farming occurs when an agreement is struck between a farmer and a buyer under which the farmer agrees to produce a commodity in a specified way and the buyer agrees to purchase it at a given date. As the commodity must be produced to certain specifications, the buyer often provides the farmer with inputs such as fertiliser on credit and offers technical assistance with production. This arrangement goes some way to alleviating the problems associated with smallholder farming. Firstly, it links farmers to markets through a direct distribution channel. Secondly, it can ease financing constraints both through the provision of inputs on credit and the fact that financial institutions can use the contract to validate that a farmer has steady income. Thirdly, it can provide a conduit for educating farmers about best practice techniques and introducing new technologies. Finally, it can improve food safety through the enforcement of standards by the buyer.

Despite the advantages, contract farming does entail costs for both parties. The buyer must draw up, monitor and enforce the contract, as well as providing technical services. On the other side, the farmer surrenders some autonomy in production decisions. As a result, contract farming is only justifiable when the benefits outweigh these transaction costs. According to Minot (2007), contract farming is suitable when:

1. The buyer is a large firm (i.e. a processor or supermarket chain). This is because the buyer needs a team of field agents who negotiate terms with farmers, distribute inputs, provide technical assistance and collect the product.

2. The product is characterised by large quality variations, perishability, technically difficult production or is high value.

3. When the destination market is willing to pay a premium for certain product attributes that can only be assured through close coordination.

4. When the policy environment is conducive. In particular, this is the case in regions with a favourable investment climate, limited regulations on direct transactions between companies and farms, well defined grades and standards and the presence of farmer organisations that link farmers and firms.

In China, the government often plays a significant role in contract farming arrangements, establishing links between the purchasing firm and farmers. The participating firms are selected on the basis of criteria including capacity to provide technology and training, and receive preferential treatment such as government loans and access to land (Lohmar et al., 2009). Nevertheless, by examining farmer surveys from villages mostly in Zhejiang, Jiangxi and Shandong provinces, Guo and Jolly (2009) conclude that the proportion of households engaged in contract farming is relatively low and well below the proportion willing to produce under contract, owing to an absence of opportunities. The households in the survey identify price stability and market access as the key motivations to contract farming. 
28. Continued growth in the market entry of new private financial institutions will help expand rural lending further and develop new financial products. As the rural market evolves, the central government should encourage the development of credit rating systems that improve the ability for new institutions to access funding. By the same token, a clearer definition of land rights, greater land transfer or an expansion of contract farming relationships (Box 3) will help provide collateral which banks can lend against.

\section{Spurring innovation in rural China}

29. In addition to reforms that improve resource allocation, the productivity of China's agricultural sector will benefit from a policy environment that fosters innovative capacity. The potential for innovation to boost agricultural output is significant given that, once disseminated, a single productivity-enhancing idea may be implemented in farms across many different regions.

30. The public sector has traditionally been the main source of agricultural research and development $(\mathrm{R} \& \mathrm{D})$ in China. Coinciding with increasing rates of privatisation, agribusinesses have increasingly invested in their own innovation activity since 2000. Even so, public agricultural R\&D has continued to expand rapidly, mostly in the form of technological development rather than basic research. Hu et al. (2011) document that while public basic research has encouraged private agricultural R\&D, public technology development has crowded out private R\&D. In future, the authorities should ensure that government agricultural $R \& D$ does not discourage private $R \& D$ investment.

31. Innovation also occurs outside formal R\&D programmes: institutions that expose farmers to new technologies and facilitate knowledge spillovers may incubate new ideas and farming processes. Such institutions include farmer cooperatives, which are increasingly being promoted, under the aegis of the 2007 Farmer Specialised Cooperative Law. Their number has increased rapidly, though with considerable differences across provinces. Focusing on Northwest China, Garnevska et al. (2011) conclude that a stable legal environment along with financial and technical support from governments and non-government organisations are important to the success of cooperatives.

32. Agricultural innovation can also benefit from exposure to new foreign technologies. The high and rising stock of agricultural $R \& D$ as well as the increasing presence of foreign firms in the agriculture sector may improve China's ability to absorb new foreign inventions (Andrews and Westmore, 2014). Foreign direct investment (FDI) is encouraged in most parts of the agricultural industry, although there are some restrictions. Changes to China's foreign investment catalogue in 2007 raised restrictions on FDI in five agricultural industries including seed production and development, soybean processing and distribution services. In addition, an update in 2011 expanded restrictions to the areas of grain purchasing and the processing of rice, flour and edible oils. It must be ensured that further amendments to the catalogue take into account the beneficial impact of FDI through knowledge spillovers to domestic firms.

33. The acceleration of China's agricultural $R \& D$ and the development of farmer cooperatives and foreign firms in the sector have been accompanied by a swelling of patenting activity. A proxy for innovation activity, the number of agricultural patents granted quadrupled between 2008 and 2013 (Figure 9). While the share of agriculture in the total economy declined, innovation intensity in the agricultural sector kept pace with China's economy as a whole in the past decade. 
Figure 9. Proxies for agricultural innovation in China suggest a recent pick-up in activity

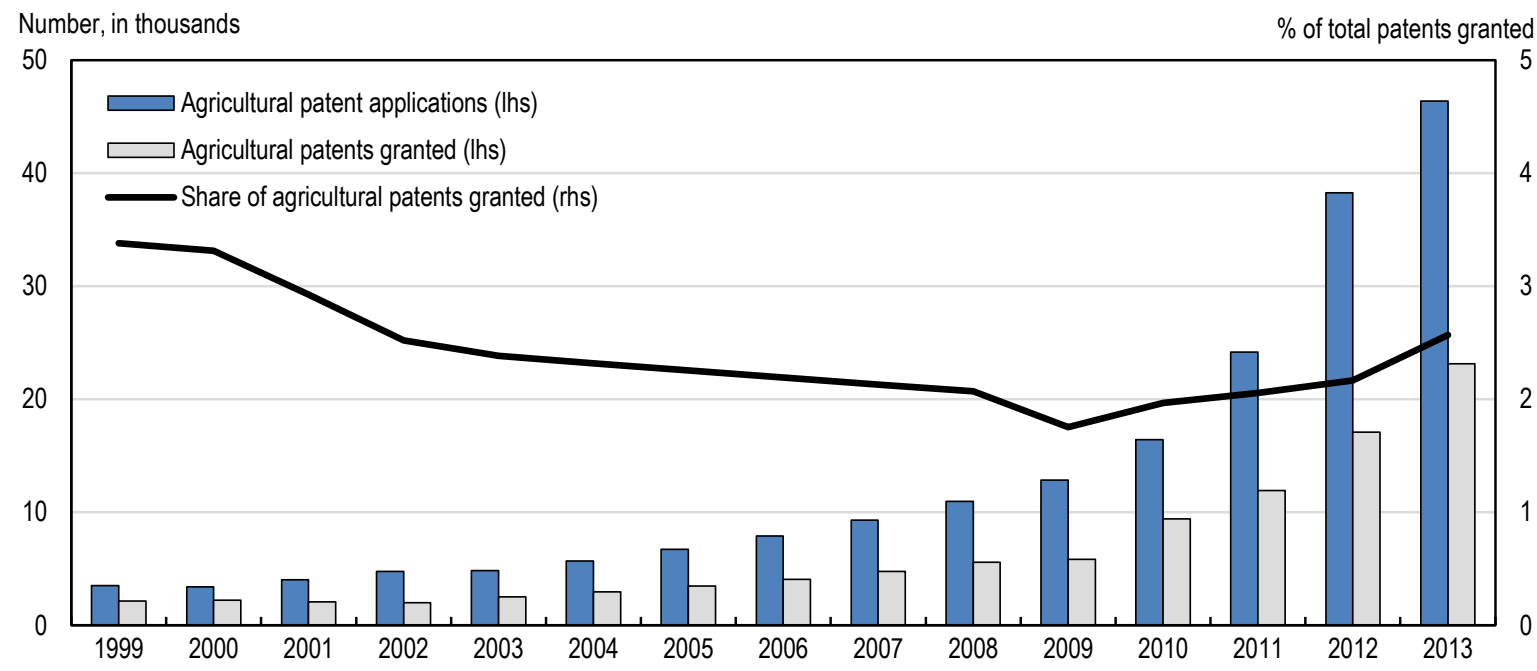

Note: Missing data for 2004-07 are approximated through linear interpolation.

Source: China Statistical Yearbook various years, authors' calculations.

34. The recent increase in agricultural patenting may have also been encouraged by improvements to China's system of intellectual property rights. Since joining the World Trade Organisation in 2001, the intellectual property rights framework has been aligned more closely with the system in OECD countries and there has been an effort to improve enforcement with the adoption of the National Intellectual Property Strategy in 2008. With stronger patent rights, the private returns to innovation activity have risen. However, concerns remain with regard to issues such as infringement and the production of counterfeit goods. The number of intellectual property rights cases brought before Chinese courts tripled between 2009 and 2013. Subsequently, China's Leading Group of Overall Reform has established specific courts in Beijing, Shanghai and Guangzhou focusing on intellectual property. Transparency as well as the extent of judicial efficiency and independence will be important determinants in how effective these institutions are in protecting intellectual property rights and private returns to innovation.

35. Outside of the agricultural sector, government policies can promote broader innovation in the rural economy. Strengthening patent rights and further rural financial development will be beneficial, but so will measures that encourage knowledge spillovers and reduce barriers to firm entry into rural sectors. The existence of entrepreneurs is important for the accumulation of knowledge-based assets and can benefit from the reduction of regulations that impose high fixed costs on firms (Andrews and Criscuolo, 2013). The World Bank Doing Business Indicators suggest that both the number of procedures and time required to start a business is substantially higher in China than in the average OECD country, suggesting scope for reform (World Bank, 2013a). Furthermore, entrepreneurial activities may be particularly likely to be undertaken by rural migrants returning from working in urban China (Démurger and $\mathrm{Xu}, 2011$ ). In such cases, new businesses are often funded through repatriated earnings, suggesting that reforms that reduce restrictions on urban migration and promote the repatriation of capital can promote rural innovation.

\section{Improvements in farmer education and re-training}

36. As Chinese agriculture continues to modernise, farmers need to have the skills to translate new technologies into productivity gains. This will also be important in the context of shifting consumer demand patterns away from traditional grain consumption as household incomes rise. Assuming that China's consumption preferences further converge to those of advanced countries, per capita consumption 
of livestock and fish protein in China will continue to increase (Fukase and Martin, 2014). If changes in the composition of agricultural production are to at least partly reflect these patterns, the ability of farmers to have broad skills that allow them to adjust farm output will be critical.

37. Skills can be acquired through the formal education system by attending agricultural universities and technical schools. For established farmers, skills can be obtained through government programmes or from upstream businesses in a contract farming relationship (Box 3).

38. China has a considerable network of agricultural extension services. These are generally provided at village and township level, reflecting the diverse needs of farmers in different rural areas and the importance of farmers being able to easily access extension agents. Although the majority of such services are still provided by the government, since the early 1990s reforms have been introduced to gradually privatise aspects of public agricultural extension (Hu et al., 2010). These changes may have had adverse effects with some evidence suggesting that declines in government funding have caused extension agents to spend an increasing amount of time on administrative and commercial activities (Lohmar et al., 2011). Asked about the types of services that they need most, farmers in Shandong, Shanxi and Ningxia provinces emphasise information about new technologies as well as assistance in seed and fertiliser selection (Zhong, 2014). Given the public good properties of the ideas disseminated through extension services, there is a rationale for continued government provision.

39. The traditional agricultural extension programmes must evolve to better meet the needs of farmers. One concept being tried out is that of farmer field schools, a learning-by-doing method of tailored farmer education that is provided at the village level on demonstration plots with a group of local farmers. The emphasis on group learning is designed to build networks and acknowledges the externalities that can result from farming practices in a local community. For example, misuse of pesticides and fertilisers may have implications for the crops of other farmers nearby. Through randomized control trials in five counties in Hebei and Anhui provinces, Burger et al. (2014) find only tentative evidence of the beneficial impact of attendance in a field school programme on farmers fertiliser use. They observe significant heterogeneity in the quality of the programmes, suggesting that training and performance-based incentives for facilitators will be important for any broader roll-out of farmer field schools.

40. Improvements in farmers' skills and the increasing introduction of modern technologies into the food production process will lower the potential for food losses (Box 4) and the contamination of food products. Food safety risks have arisen numerous times over the past decade, such as when traces of carcinogenic drugs administered by farmers were found in turbot in Beijing and Shanghai (Gale and Buzby, 2009). The resulting food safety concerns have spurred a burgeoning quantity of imports to substitute for domestic products that consumers fear are unsafe. For example, following contamination of infant formula in 2008, demand for imported baby formula products has grown rapidly. Consequently, farmer education and modernisation of production may allay consumer fears and increase the market for Chinese agricultural producers. Such changes will be complemented by recently proposed legislation by the State Council that will increase the accountability of business operators for food safety.

41. In addition to farmer training, improvements in the quality of general education in rural China can enhance employment prospects for agricultural workers and the capacity for rural citizens to adjust to structural economic changes. Educational opportunities are improving, but the level of human capital in rural areas remains much lower than in urban areas (Molnar and Koen, 2015). At the secondary school level, the graduate-to-population ratio in rural areas was unchanged between 1998 and 2012 while it doubled in urban China. As the rural adjustment process continues to unfold, a solid general education will help rural citizens transition into work in the emerging sectors of the economy. At present, rural citizens can attend vocational high school free of charge while they must pay for general high school. Vocational education should continue to be encouraged especially given its importance for developing non- 
agricultural industry in China's rural areas. However, in order to promote flexible skills, general high school should also be free.

\section{Box 4. Food losses}

Reducing food losses in agricultural production may improve productivity and farm incomes as well as the sustainability of rural land. In addition to food waste at the consumer level, output losses are often due to inadequate farmer skills and infrastructure. For example, pre-harvest losses can occur from a lack of farmer understanding about pest control and efficient seeding techniques, while post-harvest losses can derive from poor food storage facilities.

Across a sample of studies, the average estimate of pre-harvest grain losses is around $7 \%$ of total output, with losses owing largely to pests and natural disasters (Liu, 2014). Post-harvest losses tend to result from poor handling (5\% of output) and storage ( $7 \%$ of output), which may reflect that the majority of China's grain handling is conducted manually with sacks rather than with mechanised bulk handling systems (Figure 10). These studies also note geographic heterogeneity owing to differences in climate and planting structure. In particular, households in north-eastern provinces are found to display higher post-harvest storage losses than those on the Yellow-HuaiheHaihe Plain.

\section{Figure 10. Post-harvest losses of grain are estimated to be highest from poor handling and storage}

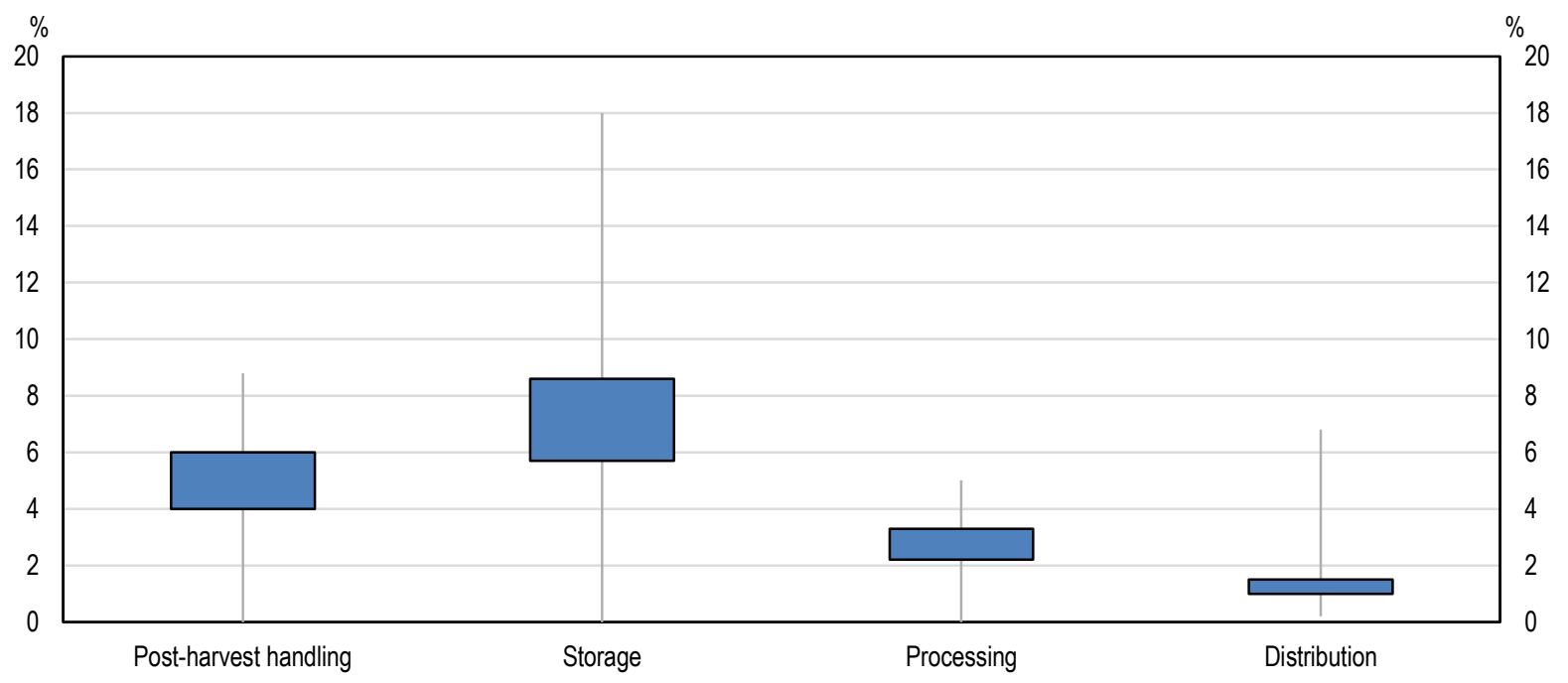

Note: Estimates are based on a survey of the empirical literature. The vertical line represents the range of estimates with the horizontal bar representing the average. The estimate for post-harvest handling is based on 19 studies, for storage on 46 studies, for processing on 17 studies and for distribution on 22 studies.

Source: Liu (2014).

\section{Land productivity and the more efficient use of natural resources}

42. More sustainable use of rural land can help improve both long-run farm productivity and the health of China's rural population. China's arable land per capita is low relative to other countries, so production methods need to preserve the fertility of land resources. Improvements in technical assistance for farmers and the diffusion of new technologies will help. So will policies that better align the price of production inputs with their true social cost. 


\section{Chemical fertilisers are overused in Chinese farming}

43. The overuse of chemical fertilisers in Chinese farming has compromised the sustainability of natural resources (Huang and Xiang, 2014). Consumption of nitrogen fertiliser per unit of arable land in China is more than double that of other countries with large agricultural sectors (Figure 11). The costs of excessive use of chemical fertiliser are significant. Soil acidity is often affected, leading to longer-term impacts on crop yields. Furthermore, nitrogen run-off can leach into lakes, rivers and coastal waters, hurting rural industries such as fishing and aquaculture in which China is expected to gain market share over the next decade (OECD-FAO, 2014). Such contamination can also taint the drinking water supply. In addition, the production of chemical fertiliser in China is a significant source of greenhouse gas emissions (Zhang et al., 2013), all the more so as this industry is far more energy and carbon-intensive in China than in most other countries, reflecting energy subsidies to fertiliser producers.

44. Fertiliser overuse may be due to artificially low prices stemming from government subsidies. These include a tax exemption on value added tax for almost all fertiliser products and a subsidy for fertiliser transportation (Huang and Xiang, 2014). Overuse is also explained by the small scale of Chinese farming, poor technical skills of agricultural producers and the increasing number of agricultural workers undertaking off-farm work. The latter effect is because such workers tend to apply fertiliser in a single large quantity rather than a more labour-intensive split application which has better nitrogen use efficiency (thus requiring less fertiliser). Therefore, land policies that promote farm consolidation and allow off-farm workers to transfer farmland operating rights to specialist agricultural producers may reduce fertiliser overuse. Such measures should be coupled with reforms that improve technical assistance for farmers and remove the price distortions from the fertiliser market so that agricultural production decisions take into account the true costs of the inputs being used. Recent efforts by the government to encourage the application of new farm technologies may also help.

Figure 11. Nitrogen fertiliser is heavily overused in China

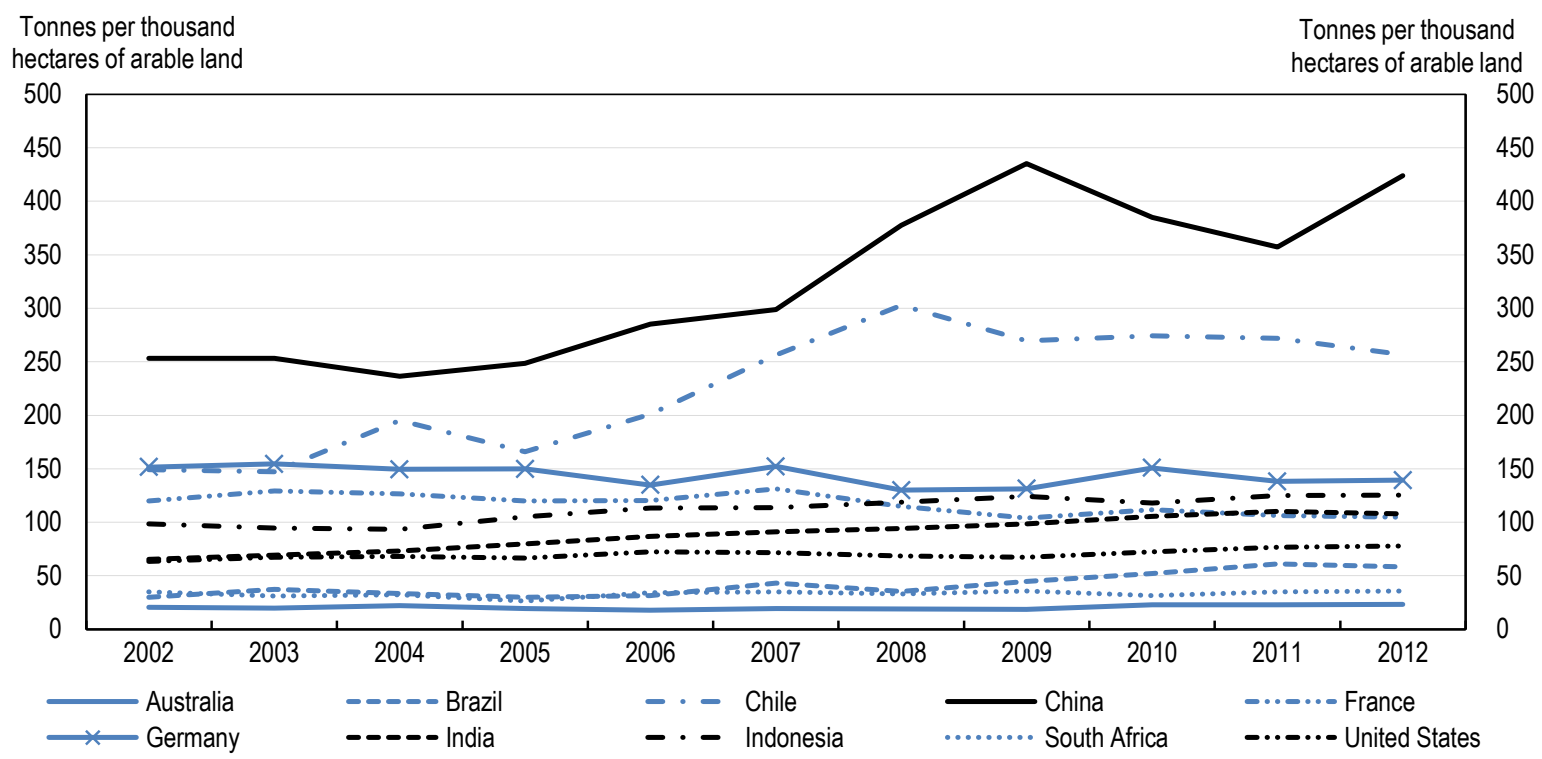

Source: FAO, authors' calculations. 


\section{ECO/WKP(2015)36}

\section{Grassland areas suffer from degradation}

45. Despite recent government reforms, China's grassland continues to suffer degradation that can have important long-term economic and ecological effects. Grassland accounts for $40 \%$ of China's total land area and is the feed base for livestock. Grasslands are also important as a "carbon sink" to alleviate greenhouse gas emissions and to lower the probability of sand storms and soil erosion. China has recently introduced policies such as the "grassland protection mechanism" aiming to restore degraded grasslands by compensating herders for reducing the number of animals that graze (Gale, 2013). However, problems of overgrazing, uncontrolled tree logging and pests continue to endanger the sustainability of China's grassland resources. In 2013, over one sixth of the country's grassland was unavailable for utilisation. With increasing consumer demand for livestock products, pressures on grassland may be further exacerbated in the coming years by a rise in China's livestock production (OECD-FAO, 2014).

46. Against this backdrop, reducing animal overstocking and promoting farmer education regarding appropriate species selection is important. For example, Henan province has begun to encourage the establishment of livestock parks that comply with a list of standards regarding environmental management and animal health. New methods can measure the capacity of a grassland plot to capture and store greenhouse gas emissions (FAO, 2014). This raises the potential for government payments to farmers who restore grassland areas linked to the associated reduction in emissions. Such steps to restore the natural environment may also support the development of related non-agricultural industries, such as agritourism, which have begun to develop in rural areas in response to gains in the average income per capita of China's households.

\section{Water resources are scarce and must be used more efficiently}

47. Efficient water use is also critical to raising China's agricultural productivity and rural living standards. Water resources are relatively scarce, with the country in the bottom half of the distribution of countries by water resources per capita in 2012. However, this masks significant geographical disparity within the country. While water scarcity is less of a problem in the southern part of China, it is a problem in the north. In particular, the Hai-Huai-Huang river basin has just $10 \%$ of the country's water resources despite having one-third of China's population and industry. This area also accounts for the majority of China's wheat production and a significant share of cotton and corn output. In response to this regional disparity, the government has undertaken the South-North Water Diversion Project, a pipeline transporting water from the Yangzi River to the north of the country. While this might add water resources for agricultural use in the north, it should be complemented by broader policies designed to promote water efficiency. Such policies are particularly important given imminent challenges to water availability such as the development of China's water-intensive shale gas industry and the prospect of increased aridity in the north of the country from further climate change. Water resources may also be depleted by rising domestic consumption of higher protein foods, as China already uses around $70 \%$ of its water-intensive maize crops for animal feed (Sharma, 2014).

48. China's water productivity is low compared with other countries, with efficiency particularly weak in the agricultural sector (World Bank, 2009). This is due to low efficiency of irrigation systems, water pollution and some misallocation of resources among crops and locations. Irrigation infrastructure has also suffered from a lack of investment partly because, for many years after the introduction of the household responsibility system, village collectives were uncertain about the extent of their legal ownership (Huang, 2014). In combination with a drop in tax revenues to collectives following the 1994 fiscal reform, this led to poor maintenance and investment in irrigation. Over recent years, irrigation infrastructure has expanded partly due to increased government funding. Between 2000 and 2013 China's effective irrigated area rose by around $40 \%$. 
49. Domestic and industrial wastewater discharges continue to be a damaging source of water pollution. Despite significant investment in urban treatment and recycling infrastructure, such infrastructure is still relatively underdeveloped in rural areas. For example, even in the wealthier Beijing and Shanghai provinces, the proportion of villages with domestic wastewater treatment facilities was $24 \%$ and 53\% respectively in 2012. Some pilot schemes, such as that governed by the prefecture-level city of Tongling in Anhui province (see Box 5), have prioritised the upgrading of water treatment facilities in local villages.

\section{Box 5. Beautiful villages project - Tongling, Anhui Province}

The Beautiful Villages project in Tongling, Anhui province is representative of many of the infrastructure projects in rural China that are being undertaken to improve the facilities of local villages. Predominantly government funded, the scheme is designed to improve village infrastructure on many fronts: solar-powered wastewater treatment facilities and payments to households for upgrading toilets aim to improve the health of the local population and fertility of the land. There is also funding for improving roads and bridges, matched funding for housing renovations and upgrades of the village landscape through maintenance of canals and vegetation.

Initially introduced in 15 villages in the prefecture, the project is to be extended to 30 villages by the end of 2014 and 100 villages by the time of project completion in 2019. An important component of the initiative is the engagement of local villagers. The project is mostly administered through village committees with significant participation by local residents; $60 \%$ of villagers are involved in some aspect of the redevelopment.

50. Very low water prices have reduced the incentive for demand management, contributing to poor water efficiency and underinvestment in water and sewerage infrastructure. Reforms have recently been announced to establish a three-tier pricing system for urban households that would raise average prices and more closely align the income share spent on water to levels observed in other countries. Such water pricing regimes should be closely monitored, not least because such schemes can have unintended redistributive consequences such as penalising larger families. Many provinces are also experimenting with a tiered pricing scheme for industrial users which could be introduced more broadly. In addition, other pilot schemes have focused on industrial water use. In Inner Mongolia, a pilot is in operation whereby downstream industries on the Yellow River invest in upstream water-saving technologies for agricultural producers in return for the rights to the saved water (Doczi et al., 2014).

51. As yet, the progress on reforms to water prices for agricultural producers has been modest. Farmers are often not charged water resource fees directly but pay an area-based charge before irrigation, leaving little incentive for water conservation (Doczi et al., 2014). Government concerns that farmer costs will rise as a result of water price reforms may be delaying policy changes. However, such reforms are necessary to ensure a sustainable agricultural sector and can be complemented by income support measures that reduce adverse impacts on rural incomes as well as farmer education that promotes greater water efficiency.

52. Along with improving water pricing regimes, reforms focusing on water allocation mechanisms are important. In 2011, the government announced a plan to enforce water use quotas for high consumption industries (Piper et al., 2012). Nevertheless, water use quotas in agriculture have so far been implemented with mixed success. Enforcement problems remain with some farmers drilling unapproved wells in order to circumvent quota restrictions, highlighting the need for close monitoring (Doczi et al., 2014). An additional mechanism may be a water trading system whereby entities are issued with tradable water permits to encourage the implementation of water saving practices and technologies. In 2014, the government selected seven provinces to host pilot markets for trade in water rights. 
53. There may be a tension between water security and the government's food security objectives. The existence of the "governor's grain bag policy", whereby each provincial governor must ensure grain demand and supply is balanced within their province, may constrain the ability of provinces to produce the most appropriate crops given local water endowments. For example, under this policy, relatively dry provinces still need to produce water-intensive crops such as rice. In future, grain quotas at the provincial level should evolve to better reflect water availability.

\section{Further government infrastructure investment in rural areas can support private activity}

54. Other types of infrastructure such as transport, electricity and IT networks will also be important to enable agricultural producers to lift productivity and to connect those wishing to pursue off-farm work or education with desirable locations. Through increasing market size, suitable infrastructure may also promote competition and the adoption of productivity-enhancing technologies. Given such positive externalities, there is often an argument for government provision. Nevertheless, it is also important that framework conditions are designed in a way that encourages private sector infrastructure investment.

55. Transport infrastructure is critical for linking agricultural producers to end markets. Without a sufficient network of roads and ports, improvements in farm productivity could result in lower local prices for a commodity at the same time as there is inadequate supply in other provinces. Transport connections within rural areas can also foster the growth of non-agricultural industries, such as food processing, that rely on farm output or new growth industries including rural tourism. Reliable electricity supply is also important for improving rural living standards and optimising farm production. It may further help mitigate output losses along the production chain by enabling mechanisation of production and appropriate storage of farm output. China is very close to achieving full electricity coverage. Nevertheless, significant future investment will be required to maintain the electricity grid and incorporate new technologies. As part of this, the Chinese government plans to invest heavily in smart grid technologies which should improve energy efficiency and provide a boost to the burgeoning renewable technology sector.

56. Investment in IT networks such as broadband can benefit agricultural production and improve rural living standards. Such infrastructure can form the basis of farm systems which help connect farmers to markets more directly and efficiently and optimise inventory management. Internet-based education programmes tailored to farmers or the general rural population become feasible with reliable broadband networks, raising farm productivity and supporting the development of non-agricultural rural industries. A well-functioning broadband network may also help increase the efficiency of China's rural social welfare systems, improving welfare assessment and targeting and better informing rural citizens about nearby services and opportunities. A recent survey covering 3000 households in Guizhou, Jilin and Shandong provinces found that only around a quarter of the villages had a facility for public internet access (World Bank, 2013b). The State Council has prioritised the completion of a national broadband network covering both urban and rural areas by 2020 . This may need to be complemented by measures that ensure internet access for low income groups.

57. China's rural infrastructure projects are mainly funded through earmarked transfers from the central to county governments. However, a substantial portion of projects are funded outside of such transfers, raising the question of which level of administration is best equipped to fund and deliver new rural infrastructure. Focusing on road investment, one survey concluded that the quality of infrastructure is higher when funding derives from the county or township government but that unit project costs tend to be lower when village leaders manage the construction themselves (Wong et al., 2013). This may reflect the fact that governments have better resources and experience in undertaking infrastructure design, while village administrations can better oversee the application of project funds on a day-to-day basis. Consequently, this encourages a collaborative approach whereby village leaders work together with the government to provide high quality rural infrastructure at the lowest cost. 
58. The success of any collaboration is likely to depend on the quality of village administration. Good village governance has been identified as a significant factor in the overall success of an infrastructure project (Liu et al., 2013). This might not just be the case for public projects. Private infrastructure investment in rural areas is also likely to depend on the quality of the local administration and the trust that firms have in village leaders.

\section{Supporting rural living standards}

59. Government policies to boost agricultural productivity will be critical for narrowing the gap between urban and rural living standards. However, the benefits to farmers of productivity-enhancing reforms may take some time to eventuate, requiring government assistance to the agricultural sector in the meantime. Furthermore, as highlighted in Figure 2, other parts of the rural community will also require government income support to ease the adjustment process. For all groups, policy measures that improve the quality of basic public services will also enhance rural living standards. Mirroring disparities in incomes, the divide between health services in urban and rural areas remains large.

60. Supporting rural living standards will benefit from well-coordinated policy measures. The 2009 OECD Rural Policy Review recommended that more formal contacts should be established between the various ministries and agencies that design rural policy in China. Looking forward, further initiatives that promote such coordination will be important.

\section{Agricultural policies to support rural incomes while minimising distortions}

61. A number of policy measures provide assistance to China's agricultural producers. The value of producer support has been growing in recent years and is now just below that in OECD countries (Figure 12). While a prime objective of these policies is income support, some measures have also been designed to promote other government aims such as the modernisation of agricultural production and grain

Figure 12. China's support for agricultural producers has risen substantially

Producer support estimate (PSE), per cent of gross farm receipts

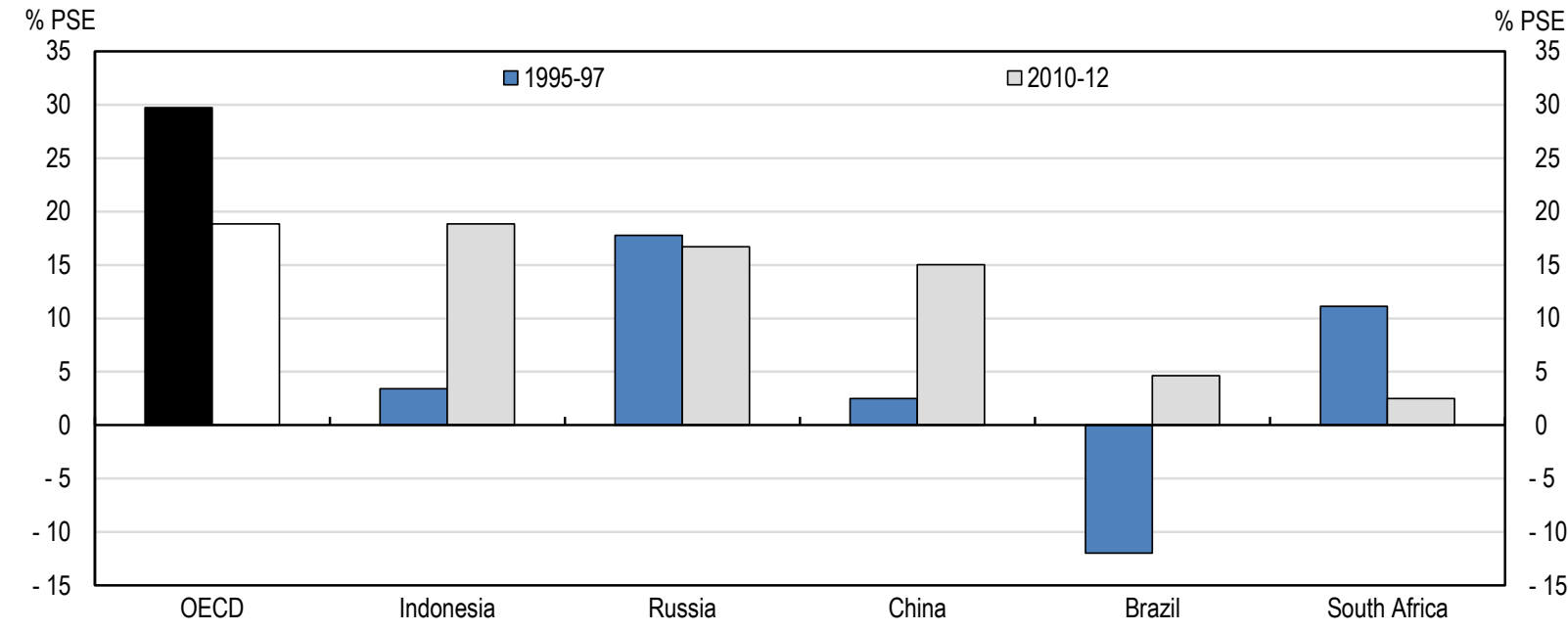

Note: The producer support estimate represents policy transfers to agricultural producers, measured at the farm gate. Transfers included in the PSE are composed of market price support, budgetary payments and the cost of revenue foregone by the government and other economic agents.

Source: OECD (2013b). 
self-sufficiency. To the extent possible, income support to agricultural producers should be provided through the social welfare system and not through introducing distortions into agricultural markets. When the government does intervene in the agricultural sector, care should be taken to ensure that policy support is designed in a way that it can be removed in the future without causing significant disruption.

\section{Agricultural support policies that also promote modernisation of production}

62. Policies that encourage the modernisation of agricultural production at the same time as supporting rural incomes include the machinery-purchase subsidy and the improved seed variety subsidy. Focusing on the first of these, purchasers receive a 30\% discount on a list of approved equipment, with the purchase price of a single item not allowed to exceed $50000 \mathrm{RMB}(\mathrm{Ni}, 2013)$. The list is updated every three years and has 185 eligible equipment types. Provinces can include additional subsidies and a further 30 items on the list. The impact of these measures on farm incomes is likely to be concentrated given that only around 3\% of farmers receive the subsidy annually (Research Center for Rural Economy, 2011). The fact that different provinces have varying levels of subsidisation may also raise arbitrage opportunities, whereby machinery is bought in a highly subsidised location and resold in a province with a less generous subsidy. Furthermore, the collation of the list of approved equipment requires judgement which has the potential to be captured by vested interests.

63. The importance of policy design can be illustrated by the historical experience with the improved seed variety subsidy. This subsidy was originally paid to seed companies viewed to produce high quality or novel seed varieties. However, allegations of corruption, abuse, and lack of benefit for farmers resulted in it being converted to a cash payment to farmers (Gale, 2013). Along with most other agricultural subsidies, the value of the improved-seed subsidy has increased rapidly over the past decade, rising tenfold between 2004 and 2012.

\section{Agricultural policies that provide income support and promote food security}

64. As discussed in Box 1, a key objective of the government's agricultural policy is to ensure food security. One way the government promotes self-sufficiency at the same time as providing income support is through subsidies to grain producers and by intervening in agricultural markets to guarantee minimum grain prices.

65. The main subsidy to grain producers is a general-input subsidy that was originally introduced to offset rising production costs. This subsidy can be adjusted upwards on an annual basis, but remains constant if input prices fall. There is also a fixed direct payment to grain producers that is administered by each province and can be based on the land holding of producers, the planted area or the volume of grain sold. Information regarding farm scale is manually compiled at the village level before being passed up to the county and then onto the provincial governments which allocate the funds (Gale, 2013). The administrative costs of this system are high and could be reduced by further progress in the development of a nationwide property register or investment in technology that enables more efficient collection of production data.

66. Minimum grain prices are implemented only in those regions that have a supply surplus, with the annual price setting based on estimates of the production costs of agricultural producers. The state-owned China Grain Reserves Corporation (Sinograin) is obliged to make intervention purchases when the market price falls below the established support price for three consecutive days. Since support prices were introduced, the minimum price has risen steadily. Between 2010 and 2014, the minimum price for rice and wheat rose by $46 \%$ and $34 \%$ respectively. This compared with a change in the world price of $26 \%$ and $-17 \%$ over the same period. As the price differential between domestic and international prices has risen, 
grain imports have increased. In 2014, China's rice imports reached 3 million tonnes, making it the world's largest rice importing country.

67. A risk in the future is that a supply or demand shock leads to a sharper fall in international prices. Assuming that the price-setting authorities (NDRC, Ministry of Agriculture and State Administration for Grain) resist a proportionate fall in minimum support prices, this may reduce the competitiveness of downstream firms given that grain imports are subject to high tariff rates relative to other commodities once the volume of imports exceed a given quota (Gale, 2013). In addition, such a scenario could lead to a sizeable increase in the scale of government support, to the extent that World Trade Organisation limits on domestic support may be breached.

68. Replacing the minimum price system with an ex post direct payment based on the difference between a target and the market price could reduce distortions in grain markets. However, administering such a policy may be difficult given it would require comparable records of the quantity of grain sold for all farmers. A more straightforward approach may be to gradually replace minimum purchase prices with a direct payment to farmers. Prices would then be determined by market conditions while farmer incomes would continue to be supported. A direct payment decoupled from production decisions would be best for ensuring production flexibility in the face of rapidly changing consumer demand patterns for food. However, in the short term, this may not be practical while the government aims at wheat and rice selfsufficiency. Instead, minimum purchase prices could be replaced by a direct payment to grain producers, implemented by raising the general-input subsidy. In the long term, the key determinant of China's capacity to maintain food security will be the ability to raise agricultural productivity growth.

69. The evolution of the European Union Common Agricultural Policy since the early 1990s is relevant in this context. Market price support was gradually reduced and replaced with direct payments to producers that were progressively decoupled from farm production decisions (OECD, 2011). For most commodities, the size of allowable government market interventions was initially lowered before interventions were eventually abolished altogether.

\section{The coverage of rural poverty reduction measures is limited and rural healthcare services are poor}

70. China's rural citizens will all benefit from improvements in government services but some groups may be more reliant on them than others. The detrimental effects of the rural adjustment process may be particularly acute for agricultural workers who are not able to keep up with sector-wide productivity gains. These may be the less able and elderly or those who are able but are transitioning to off-farm work opportunities. For these groups, a well-functioning social welfare and health system will be particularly important in easing the development process.

\section{Rural social assistance programmes}

71. Between 2010 and 2013, China's rural poverty rate halved to be $8.5 \%$ of the rural population. Even so, over 80 million people remain below the poverty line, highlighting the importance of further improvements in the social assistance coverage of the rural population. While most forms of government assistance, such as the numerous subsidies for agricultural production, are not means tested, some are specifically designed to target low-income and elderly rural citizens.

72. The rural dibao programme aims to raise rural incomes, generally through a direct payment to households equal to the difference between actual income and a determined minimum level. Between 2007 and 2010, the number of rural residents receiving the dibao rose by $50 \%$, though the coverage rate plateaued in the subsequent few years. In 2013, the recipients numbered around 65\% of those living below the poverty line. 
73. The threshold for the dibao is determined locally with reference to regional economic conditions and the eligibility of a rural citizen is largely left to the discretion of village officials. This has resulted in significant variations in the criteria and processes used to evaluate eligibility for the payment across provinces. Consequently, a number of reports of corruption in the administration of dibao have surfaced, leading to more rigid policies being outlined by the Ministry of Civil Affairs (Golan et al., 2014). One of the most promising remedies is allowing rural citizens to apply directly to the county government for dibao. However, county governments may lack the capacity to administer and thoroughly evaluate these applications. As county-level governments' information systems improve, a better design of the dibao policy will become increasingly feasible.

74. In the future, efforts should be made to expand the coverage of the dibao programme. Simulations by Golan et al. (2014) suggest that increasing the coverage of dibao would lead to a greater reduction in poverty than an increase in the value of the payments. Nevertheless, this depends on the quality of targeting for additional beneficiaries, highlighting the importance of administrative systems that allow payments to be channelled to those most in need.

75. There is also the wubao programme that aims to maintain the basic living standards of the elderly, the disabled and some children (those with no supporting family, no income and no ability to work) often through the provision of in-kind services. Benefits usually include food, clothing, medical care, housing and burial expenses. Depending on the physical condition of the person, care can be given either separately or collectively. Such policy instruments are important for safeguarding the living standards of vulnerable members of the rural population. However, they need to be complemented with good quality rural healthcare services that are readily accessible.

76. A well-functioning pension system is particularly important for supporting rural living standards in later life. There are disparities between the extent to which China's urban and rural population have been supported by pension payments. In the 2010 Population Census, 66\% of the urban population aged over 60 reported pension income as their main source of livelihood compared with $26 \%$ of those in towns and $6 \%$ of those in villages. However, since then, the coverage of the New Rural Pension Scheme which was originally introduced in 2009 has broadened substantially. The framework of the scheme is very similar to that recently adopted in urban areas: both are voluntary schemes that include a matched defined contribution element and a subsidised flat basic pension (Herd et al., 2010). The primary objective of these programmes is broad coverage with both contributions and benefits low. Indeed, the replacement rate for a rural worker is very low by international standards. The State Council intends to unify the rural and urban pension schemes, which will be aided by the similarities in the scheme designs. A unified national scheme will allow portability across areas and achieve better risk pooling. Once the national scheme is in place, steps should be taken to gradually raise benefits.

\section{China's rural health reforms}

77. Healthcare services in rural China remain limited compared with urban areas. Policy reforms to redress this imbalance are particularly important in the context of a rapidly ageing population and substantial structural change. In most provinces, the number of healthcare professionals per capita is less than half that in urban regions (Figure 13). Furthermore, there is a large differential between urban and rural China in the proportion of doctors that have a college or higher education degree (Hou et al., 2014). In 2013, the mortality rate of rural children under five years old was more than double that in urban areas.

78. Advances have been made, with the introduction of the New Cooperative Medical Scheme in rural areas promoting voluntary enrolment in health insurance programmes that are partly subsidised by government. The introduction of the scheme has raised rural residents' use of healthcare services. Going 
forward, this should be complemented by continued investment in rural health facilities so that supply keeps up with healthcare demand.

Figure 13. Healthcare services in rural China are low compared with urban areas

Ratio of medical staff per capita in urban to rural areas, 2013

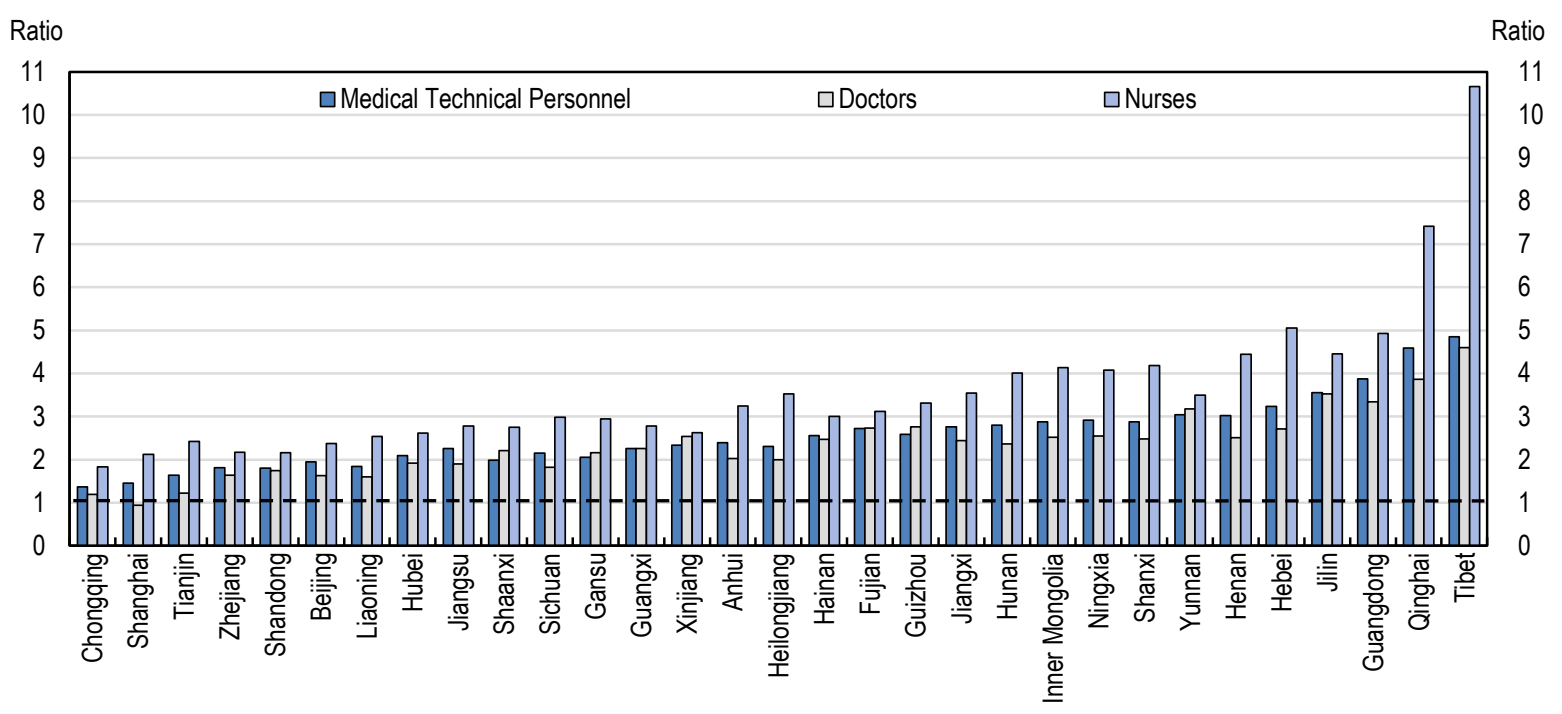

Source: China Statistical Yearbook 2014.

79. The New Cooperative Medical Scheme operates on funding from a combination of central and local governments, village committees and participants. In most cases, however, the majority of the funding burden falls on local governments, meaning funding differs markedly depending on local fiscal conditions (Dai et al., 2014). Out-of-pocket payments are likely to be largest in those areas where local governments have the poorest financing capacity. As such, the design of the scheme may be accentuating existing regional inequities, calling for a larger role for the central government in its funding.

80. In many cases, local governments only allow scheme participants to utilise health services in the local area in which their household is registered. This may constrain the capacity of some workers to migrate out of rural areas or lead to further inequities between local and migrant workers in China's cities. Future reforms should seek to allow portability of health insurance. More broadly, the urban and rural health insurance systems should be gradually integrated. While integration may entail administrative challenges, gaps in insurance coverage between the New Cooperative Medical Scheme and urban medical insurance schemes remain large (Wang et al., 2014b). A reform of this nature would be a logical step following the intended unification of the rural and urban pension systems.

\section{Conclusion}

81. China's continued urbanisation poses many challenges for the rural economy but is necessary for the country's further economic development. Government policy settings should not impede migration of rural residents to where they yield a higher marginal product by limiting access to public services or portability of social benefits. Those citizens migrating from rural areas should also be able to transfer land rights via well-regulated exchange platforms, providing them an income stream and ensuring that land is not left abandoned. 
82. At the same time as encouraging further urbanisation, measures that promote rural living standards are critical given ongoing inequities between urban and rural China. Some of these measures can benefit both the agricultural sector as well as other parts of the rural economy. These include further rural financial development, public infrastructure spending and reforms that promote innovation and the accumulation of knowledge-based assets. The government has identified a number of these areas as policy priorities and further reform action will be welcome. Given the authorities' objective of maintaining food security, policy settings that promote growth in agricultural productivity to offset the loss of workers migrating from the sector are also critical. Better defining land contract rights and improving farmers' technical skills will be important. However, distortions in both factor and product markets that undermine long-run growth in the agricultural sector, and the rural economy more generally, must also be addressed.

83. For the elderly and other rural residents struggling to adjust during this period of rapid structural change there must be a continued emphasis on expanding the coverage of government support in rural China. This involves improving healthcare, broadening the scope of social welfare payments, and, eventually, integrating public service systems between urban and rural areas.

\section{Main policy recommendations on agricultural and rural reform}

\section{Enabling the reallocation of resources}

Give certificates to all rural households detailing their land-use rights and improve enforceability.

Establish well-regulated, transparent, exchange platforms for the transfer of land operation rights for rural farmland and collectively-owned construction land.

Increase the duration of contract rights to rural farmland to 70 years, with contracts automatically renewable upon expiration.

Universally introduce resident permits for migrant workers that allow access to public services, while protecting land entitlements at their origin.

Reduce barriers to entry for microfinance institutions and develop better credit evaluation systems for rural borrowers.

\section{Improving the efficiency of agricultural production}

Gradually remove subsidies for fertiliser products.

Maintain public agricultural extension services with a particular focus on providing information about new technologies and assistance in seed and fertiliser selection.

Implement and enforce unit pricing of water for agricultural users and better water allocation mechanisms to encourage demand management and investment in water-saving technology.

Ensure collaboration between village leaders and government to provide high quality rural infrastructure at the lowest cost.

\section{Improving the administration of income support in rural areas}

Gradually replace minimum prices for grain with direct payments to farmers.

Expand the coverage of the dibao programme and provide adequate funding to county governments to assess applications.

Increase the role of the central government in funding the New Cooperative Medical Scheme and allow portability of the scheme's coverage. 
ECO/WKP(2015)36

\section{Bibliography}

Alston, J. and P. Pardey (2014), “Agriculture in the Global Economy”, Journal of Economic Perspectives. Vol. 28.

Andrews, D and C. Criscuolo (2013), "Knowledge-Based Capital, Innovation and Resource Allocation", OECD Economics Department Working Papers, No. 1046, OECD Publishing, Paris.

Andrews, D. and B. Westmore (2014), "Managerial Capital and Business R\&D as Enablers of Productivity Convergence", OECD Economics Department Working Papers, No. 1137, OECD Publishing, Paris.

Boao Review (2013), Report on Small and Microbusiness Financing: Chinese Experience and Asian Paths, http://www.boaoreview.com/

Burger, N., M. Fu, K. Gu, X. Jia, K. Kumar, G. Mingliang (2014), “Assessing the Impact of Farmer Field Schools on Fertilizer Use in China", International Initiative for Impact Evaluation, August.

Central Committee of the Communist Party and the State Council (2015), "The No. 1 Central Document: Deepening Reforms and Innovation to Accelerate Agricultural Modernisation”, Beijing.

Chang, H., Y. Yu and Y. Guo (2012), "Development Model and Characteristics of Rural Land Joint StockCooperative System", Asian Agricultural Research, Vol. 4.

Chan, K. (2013), “China, Internal Migration”, in The Encyclopedia of Global Migration, Blackwell Publishing.

Dai, B., L. Zhou, Y.J. Mei and C. Zhan (2013), "Regional Inequity in Financing New Cooperative Medical Scheme in Jiangsu, China", The International Journal of Health Planning and Management, Vol. 29.

Démurger, S. and H. Xu (2011), "Return Migrants: The Rise of New Entrepreneurs in Rural China", World Development, Vol. 39.

Ding, Q. and M. Lin (2013), “Social Services Management of Floating Population Residence”, Donyue Tribune, Vol. 34.

Doczi, J., R. Calow and V. d'Alancon (2014), "Growing More with Less: China's Progress in Agricultural Water Management and Reallocation”, Case Study Report, Overseas Development Institute.

Duflos, E. and L. Ren (2014), “Financial Inclusion in China: Will Innovation Bridge the Gap?”, CGAP.

FAO (2013), 2000 World Census of Agriculture: Analysis and international comparison of the results (1996-2005), FAO Statistical Development Series.

FAO (2014), "FAO and Chinese Partners Working to Unlock Carbon Finance for Herders and Grazers", Media Release, 30 May. Rome.

Feng, L., J. Ye., Y. Jiang and K. Zhu (2011), "The Sequential Variation and Regional Difference of Land Reallocation in Rural China: An Empirical Study Based on a Survey in 17 Provinces from 1999 to 2010", China Land Science, Vol. 25. 
Fuglie, K. (2012), "Productivity Growth and Technology Capital in the Global Agricultural Economy ", in Fuglie, K., S. Wang and V. Ball (eds.), Productivity Growth in Agriculture: An International Perspective, CAB International, Wallingford, UK.

Fukase, E. and W. Martin (2014), "Who Will Feed China in the $21^{\text {st }}$ Century? Income Growth and Food Demand and Supply in China", The World Bank Policy Research Working Papers, No. 6926.

Gale, F. and J.C. Buzby (2009), "Imports From China and Food Safety Issues", Economic Research Service Economic Information Bulletin, No. 52.

Gale, F. (2013), "Growth and Evolution in China's Agricultural Support Policies", Economic Research Service Economic Research Report, No. 153.

Gao, L., J. Huang and S. Rozelle (2012), "Rental Markets for Cultivated Land and Agricultural Investments in China", Agricultural Economics, Vol. 43.

Geraci, M., M. Luan and C. Dixon (2010), "Microcredit in China: Recommendations for Policy Makers", The Global Policy Institute Policy Papers, No. 15.

Giles, J. and R. Mu (2014), "Village Political Economy, Land Tenure Insecurity, and the Rural to Urban Migration Decision: Evidence from China", World Bank Policy Research Working Paper, No. 7080.

Golan, J., T. Sicular and N. Umapathi (2014), “Any Guarantees? China's Rural Minimum Living Standard Guarantee Program”, World Bank Social Protection \& Labor Discussion Papers, No. 1423.

Herd, R., Hu, H and V. Koen (2010), "Providing Greater Old-Age Security in China", OECD Economics Department Working Paper, No. 750, OECD Publishing, Paris.

Hoken, H. (2012), "Development of Land Rental Market and its Effect on Household Farming in Rural China: An Empirical Study in Zhejiang Province”, IDE Discussion Papers, No. 323.

Hou, J., et al. (2014), "Transformation of the Education of Health Professionals in China: Progress and Challenges", The Lancet, Vol. 384.

Huang, J., X. Wang and H. Qui (2012), "Small-scale Farmers in China in the Face of Modernisation and Globalisation", IIED/HIVOS, London/The Hague.

Huang, J. and C. Xiang (2014), “Fertilizer Subsidies in China: Which Way Forward?”, International Food and Agricultural Trade Policy Council Discussion Paper, forthcoming.

Huang, Q. (2014), "Impact Evaluation of the Irrigation Management Reform in Northern China", Water Resources Research, Vol. 50.

Hu, R., C. Yaqing, K.Z. Chen, C. Yongwei, J. Huang (2010), "Effects of Inclusive Public Agricultural Extension Service: Results from a Policy Reform Experiment in Western China", IFPRI Discussion Papers, No. 01037.

Hu, R., Q. Liang, C. Pray, J. Huang and J. Yanhong (2011), "Privatization, Public R\&D Policy, and Private R\&D Investment in China's Agriculture", Journal of Agricultural and Resource Economics, Vol. 36. 
Hu, R. (2012), “China's Agricultural Innovation System: Issues and Reform”, in Improving Agricultural Knowledge and Innovation Systems, OECD Conference Proceedings.

Khantachavana, S.V., C. Turvey, R. Kong and X. Xianli (2013), "On the Transaction Values of Land Use Rights in Rural China", Journal of Comparative Economics, Vol. 41.

Koen, V., R. Herd and S. Hill (2013), "China's March to Prosperity: Reforms to Avoid the Middle-Income Trap”, OECD Economics Department Working Papers, No. 1093.

Kuhn, P. and K. Shen (2014), "Do Employers Prefer Undocumented Workers? Evidence from China's Hukou System", IZA Discussion Paper Series, No. 8289.

Liu, C., L. Zhang, J. Huang, R. Luo and H. Yi (2013), "Project Design, Village Governance and Infrastructure Quality in Rural China”, China Agricultural Economic Review, Vol. 5.

Liu, G. (2014), "Food Losses and Food Waste in China: A First Estimate", OECD Food, Agriculture and Fisheries Papers, No. 66.

Lohmar, B., F. Gale, F. Tuan and J. Hansen (2009), "China's Ongoing Agricultural Modernization: Challenges Remain After 30 Years of Reform", US Department of Agriculture Economic Research Service Economic Information Bulletin, Vol. 51.

Lohmar, B. (2013), "Planting the Seeds of Reform", China Economic Quarterly, Vol. 17.

MacDonald, J. (2011), "Why are Farms Getting Larger? The Case of the US", German Association of Agricultural Economists Meeting.

Ma, X., N. Heerink, S. Feng, X. Shi (2015), "Farmland Tenure in China: Comparing Legal, Actual and Perceived Security", Land Use Policy, Vol. 42.

Minot, N (2007), "Contract Farming in Developing Countries: Patterns, Impact, and Policy Implications", in Case Study \#6-3 of the program: Food policy for developing countries: the role of government in the global food system".

Molnar, M. and V. Koen (2015), "Providing the Right Skills to All in China", OECD Economics Department Working Papers, forthcoming.

NBS (2010), China Statistical Yearbook: 2010, National Bureau of Statistics of China.

Ni, H. (2013), "Agricultural Domestic Support and Sustainable Development in China", ICTSD Programme on Agricultural Trade and Sustainable Development, May.

Ong, L.H. (2013), “China's Banking System and Access to Credit”, Testimony before the US-China Economic and Security Review Commission, March 7.

OECD (2011), Evaluation of Agricultural Policy Reforms in the European Union, OECD Publishing, Paris.

OECD (2013a), OECD Economic Surveys: China 2013, OECD Publishing, Paris.

OECD (2013b), Agricultural Policy Monitoring and Evaluation 2013: OECD Countries and Emerging Economies, OECD Publishing, Paris. 
OECD (2014), Agricultural Policy Monitoring and Evaluation 2014: OECD Countries, OECD Publishing, Paris.

OECD (2015), National Urban Policy Review: China, OECD Publishing, Paris.

OECD-FAO (2013), OECD-FAO Agricultural Outlook 2013-2022, OECD Publishing, Paris.

OECD-FAO (2014), OECD-FAO Agricultural Outlook 2014-2023, OECD Publishing, Paris.

Piper, B., Z. Wang and L. Sihui (2012), "EU-China River Basin Management Programme”, Water Resource Supply Security Strategy Analysis: Technical Report, No. 75.

Research Center for Rural Economy (2011), “Chinese Rural Policy Implementation Report”, November.

Research Institute of Economy, Trade \& Industry (2014), "Rural Land Circulation in China Gaining Momentum: The Increasing Role of Trust Companies", www.rieti.go.jp/en/china/14030701.html.

Sharma, S. (2014), “The Need for Feed: China's Demand for Industrialized Meat and its Impacts”, Institute for Agriculture and Trade Policy.

State Council (2010), "Guidance Relating to the Dipiao Pilot Scheme", State Council Information Update, No. 47.

Wang, X. and R. Herd (2013), "The System of Revenue Sharing and Fiscal Transfers in China", OECD Economics Department Working Papers, No. 1030.

Wang, X., F. Yamauchi, K. Otsuka and J. Huang (2014a), "Wage Growth, Landholding and Mechanization in Chinese Agriculture", World Bank Policy Research Working Papers, No. 7138.

Wang, X., A. Zheng, X. He and H. Jiang (2014b), "Integration of rural and urban healthcare insurance schemes in China: an empirical research", BMC Health Services Research, Vol. 14.

Wong, H.L., R. Luo, L. Zhang and S. Rozelle (2013), "Providing Quality Infrastructure in Rural Villages: The Case of Rural Roads in China", Journal of Development Economics, Vol. 103.

World Bank (2009), Addressing China's Water Scarcity: Recommendations for Selected Water Resource Management Issues, Washington DC.

World Bank (2011), "Implementation Completion and Results Report on a Loan in the Amount of US\$100 Million to the People's Republic of China for a Micro and Small Enterprise Finance Project", December 19.

World Bank (2013a), Doing Business 2014: Understanding Regulations for Small and Medium-Size Enterprises, The World Bank, Washington DC.

World Bank (2013b), "China: Improving Rural Access to Information and Communication Technologies", http://www.worldbank.org/en/news/feature/2013/01/29/china-improving-rural-access-toinformation-communication-technologies

World Bank and Development Research Center of the State Council (DRC), the People's Republic of China (2014), Urban China: Toward Efficient, Inclusive and Sustainable Urbanization, Washington 
DC.Yuen, S. (2014), “China's New Rural Land Reform? Assessment and Prospects”, CEFC News Analysis, No. 2014/1.

Zhang, W., D. Zheng-xia, P. He, X. Ju, D. Powlson, D. Chadwick, D. Norse, Y. Lu, Y. Zhang, L. Wu, X. Chen, K.G. Cassman and F. Zhang (2013), "New Technologies Reduce Greenhouse Gas Emissions from Nitrogenous Fertilizer in China", Proceedings of the National Academy of Sciences of the United States of America, Vol. 110.

Zhong, Z. (2014), "Chinese Agricultural Extension: History, Current Status and Supply-Demand Characteristics", Asian-Pacific Information Platform on Agricultural Policy.

Zhou, Z. (2010), “Achieving Food Security in China: Past Three Decades and Beyond”, China Agricultural Economic Review, Vol. 2. 
ECO/WKP(2015)36

\section{WORKING PAPERS}

The full series of Economics Department Working Papers can be consulted at www.oecd.org/eco/workingpapers

1217. A snapshot of China's service sector

(May 2015) by Margit Molnar and Wei Wang

1216. Does the post-crisis weakness of global trade solely reflect weak demand?

(May 2015) by Patrice Ollivaud and Cyrille Schwellnus

1215. Estonia: raising productivity and benefitting more from openness

(May 2015) by Andreas Kappeler

1214. Estonia: making the most of human capital

(May 2015) by Andrés Fuentes Hutfilter

1213. The Czech labour market: documenting structural change and remaining challenges

(May 2015) by Sónia Araújo and Petr Malecek

1212. Reforming the Slovak public sector

(April 2015) by Lilas Demmou and Robert Price

1211. Spurring growth in lagging regions in the Slovak Republic

(April 2015) by Lilas Demmou, Gabriel Machlica and Martin Haluš

1210. Skill mismatch and public policy in OECD countries

(April 2015) by Müge Adalet McGowan and Dan Andrews

1209. Labour market mismatch and labour productivity: evidence from PIAAC data

(April 2015) by Müge Adalet McGowan and Dan Andrews

1208. Maintaining an efficient and equitable housing market in Belgium

(April 2015) by Sanne Zwart

1207. Determinants of the low female labour force participation in India

(April 2015) by Piritta Sorsa, Jan Mares, Mathilde Didier, Caio Guimaraes, Marie Rabate,

Gen Tang and Annamaria Tuske

1206. Strengthening skill use and school-to-work transitions in the Czech Republic

(April 2015) by Sónia Araújo and Petr Malecek

1205. Reforming the tax on immovable property: taking care of the unloved

(April 2015) by Hansjörg Blöchliger

1204. Taxation and investment in Colombia

(April 2015) by Sarah Perret and Bert Brys 
1203. Efficiency and contestability in the Colombian banking system (April 2015) by Christian Daude and Julien Pascal

1202. Fiscal decentralisation in Colombia: new evidence regarding sustainability, risk sharing and "fiscal fatigue"

(April 2015) by Guillaume Bousquet, Christian Daude and Christine de la Maisonneuve

1201. Effects of economic policies on microeconomic stability

(April 2015) by Boris Cournède, Paula Garda and Volker Ziemann

1200. The 2013 update of the OECD's database on product market regulation - policy insights for $O E C D$ and non-OECD countries

(April 2015) by Isabell Koske, Isabelle Wanner, Rosamaria Bitetti and Omar Barbiero

1199. Improving taxes and transfers in Australia

(April 2015) by Philip Hemmings and Annamaria Tuske

1198. Federal-state relations in Australia

(April 2015) by Vassiliki Koutsogeorgopoulou and Annamaria Tuske

1197. Sharing the fruits of growth with all Mexicans

(April 2015) by Eduardo Olaberriá and Valéry Dugain

1196. What makes Mexicans happy?

(April 2015) by Valéry Dugain and Eduardo Olaberriá

1195. Improving the labour market integration of immigrants in Belgium

(March 2015) by Álvaro Pina, Vincent Corluy and Gerlinde Verbist

1194. Raising the potential of the domestically oriented sector in Germany

(March 2015) by André Eid and Andrés Hutfilter

1193. Improving transport infrastructure in Russia

(March 2015) by Alexander Kolik, Artur Radziwill and Natalia Turdyeva

1192. Improving the business climate in Russia

(March 2015) by Arthur Radziwill and Yana Vaziakova

1191. Determinants of female entrepreneurship in India

(March 2015) by Arnaud Daymard

1190. The changing role of the exchange rate for macroeconomic adjustment

(March 2015) by Patrice Ollivaud, Elena Rusticelli and Cyrille Schwellnus

1189. Boosting productivity in Russia: skills, education and innovation

(March 2015) by Lilas Demmou and Andreas Wörgötter 